OPEN ACCESS

Edited by:

Matthew Collins,

University of Exeter, United Kingdom

Reviewed by:

Tereza Cavazos,

Center for Scientific Research and

Higher Education in Ensenada

(CICESE), Mexico

Juliana Anochi,

National Institute of Space Research

(INPE), Brazi

*Correspondence:

Nathalie Hilm

hilmi@centrescientifique.mc

Specialty section:

This article was submitted to

Predictions and Projections,

a section of the journal

Frontiers in Climate

Received: 16 May 2021

Accepted: 11 August 2021

Published: 07 September 2021

Citation:

Hilmi N, Chami R, Sutherland MD,

Hall-Spencer JM, Lebleu L,

Benitez MB and Levin LA (2021) The

Role of Blue Carbon in Climate

Change Mitigation and Carbon Stock

Conservation. Front. Clim. 3:710546.

doi: 10.3389/fclim.2021.710546

\section{The Role of Blue Carbon in Climate Change Mitigation and Carbon Stock Conservation}

\author{
Nathalie Hilmi ${ }^{1 *}$, Ralph Chami ${ }^{2}$, Michael D. Sutherland ${ }^{3}$, Jason M. Hall-Spencer ${ }^{4,5}$, \\ Lara Lebleu ${ }^{1,6}$, Maria Belen Benitez ${ }^{1}$ and Lisa A. Levin ${ }^{7}$ \\ ${ }^{1}$ Environmental Economics, Centre Scientifique de Monaco, Monaco, Monaco, ${ }^{2}$ Institute for Capacity, The International \\ Monetary Fund, Washington, DC, United States, ${ }^{3}$ Department of Geomatics Engineering and Land Management, Faculty of \\ Engineering, The University of the West Indies, St. Augustine, Trinidad and Tobago, ${ }^{4}$ School of Biological and Marine \\ Sciences, University of Plymouth, Plymouth, United Kingdom, ${ }^{5}$ Shimoda Marine Research Center, University of Tsukuba, \\ Tsukuba, Japan, ${ }^{6}$ Sea Mammal Research Unit, Scottish Oceans Institute, University of St Andrews, St Andrews, \\ United Kingdom, ${ }^{7}$ Center for Marine Biodiversity and Conservation and Integrative Oceanography Division, Scripps \\ Institution of Oceanography, UC San Diego, La Jolla, CA, United States
}

The potential for Blue Carbon ecosystems to combat climate change and provide co-benefits was discussed in the recent and influential Intergovernmental Panel on Climate Change Special Report on the Ocean and Cryosphere in a Changing Climate. In terms of Blue Carbon, the report mainly focused on coastal wetlands and did not address the socio-economic considerations of using natural ocean systems to reduce the risks of climate disruption. In this paper, we discuss Blue Carbon resources in coastal, open-ocean and deep-sea ecosystems and highlight the benefits of measures such as restoration and creation as well as conservation and protection in helping to unleash their potential for mitigating climate change risks. We also highlight the challenges-such as valuation and governance-to marshaling their mitigation role and discuss the need for policy action for natural capital market development, and for global coordination. Efforts to identify and resolve these challenges could both maintain and harness the potential for these natural ocean systems to store carbon and help fight climate change. Conserving, protecting, and restoring Blue Carbon ecosystems should become an integral part of mitigation and carbon stock conservation plans at the local, national and global levels.

Keywords: ecosystem services, mitigation, carbon services valuation, governance, environmental economics

\section{INTRODUCTION}

The ongoing global COVID-19 pandemic and its global human and economic repercussions brings to the fore the recognition that the sustainability of our economic systems very much depends on the sustainability of ecosystems and biodiversity. The current climate change crisis is threatening economies as it is accelerating losses of marine biodiversity and habitats (Bindoff et al., 2019). There is an increased awareness of the severe impact of damage to the natural world on social and economic well-being, and a growing urgency in calls to make (or demand) changes that will put societies on a more sustainable path. To date, conservation appeals have not attracted investment in natural capital at the level needed, nor have appeals to focus on mitigating the effects of the climate crisis. There is a dire need for a change in societal mindsets toward those that recognize nature as invaluable to our economic well-being. 
The pandemic has shaken a number of assumptions common to modern societies regarding the relationship between people and the natural world-an extractive view of natureexemplifying the high cost and great vulnerability inherent in this outdated mentality. International lockdowns revealed the positive effects of reduced anthropogenic disturbance on natural ecosystems. Governments and industries have been able to adapt rapidly and radically to mitigate the worldwide pandemic risk to societies. This has laid bare the old arguments that rapid adaptation is not possible at the scale needed to reduce the threats of climate change.

Marine ecosystems require far greater attention than received thus far as a means of securing humanity's future health and well-being (Laffoley, 2020; Laffoley et al., 2020). Those marine ecosystems that contribute to climate change mitigation by sequestering excess carbon from the atmosphere are known as Blue Carbon ecosystems. The Intergovernmental Panel on Climate Change (IPCC) defines Blue Carbon as "All biologicallydriven carbon fluxes and storage in marine systems that are amenable to management." The focus has been on rooted vegetation in the coastal zone, such as tidal marshes, mangroves and seagrasses. These ecosystems have high carbon burial rates on a per unit area basis and accumulate carbon in their soils and sediments. They provide many non-climatic benefits and can contribute to ecosystem-based adaptation to climate change. If degraded or lost, coastal blue carbon ecosystems are likely to release most of their carbon back to the atmosphere. There is current debate regarding the application of the blue carbon concept to other coastal and non-coastal processes and ecosystems, including the open ocean." (Weyer et al., 2019).

Many natural processes and ecosystem components contribute to carbon sequestration and burial; when these are disrupted additional carbon previously stored can be released into the ocean or atmosphere. We refer to protection of these processes and stores as carbon stock conservation, an action that is transitional between mitigation and adaptation. There is a gradient in anthropogenic influence on natural ocean carbon stocks and their value ranging from destruction and degradation (inducing carbon loss) to restoration and creation (enhancing carbon) with maintenance and protection of existing carbon storage as neutral (Figure 1). Despite their importance, these blue carbon concepts are not yet uniformly incorporated into climate strategies on local, national and global scales. The reasons for this include variability in ecosystem impacts, uncertain carbon fluxes and trajectories, valuation methods and governance strategies. Resolving these challenges would go a long way in enhancing the efforts to include these natural solutions to climate change into both mitigation and carbon stock conservation strategies, where they can be beneficial to a country's sustainable development.

The Special Report on the Ocean and Cryosphere in a Changing Climate (SROCC) (IPCC, 2019) provides policy makers and other parties with a holistic perspective on the current state of the ocean in the face of increasing problematic impacts of climate change. The report identifies knowledge gaps and uncertainties which limit the design and implementation of mitigation strategies in the UNFCCC policy framework. It introduces Blue Carbon-driven ecological and economic climate change mitigation measures and identifies two management approaches in Chapter 5 (Bindoff et al., 2019) (i) Actions to maintain the integrity of natural carbon stores, decreasing their potential release of greenhouse gasses and (ii) Actions that enhance the long-term removal of greenhouse gasses from the atmosphere by marine systems. SROCC briefly discusses ocean processes such as the biological and microbial pumps that transform and transport carbon, and reviews approaches to ocean management for climate presented in Gattuso et al. (2018). SROCC highlights the release of carbon due to disturbance to coastal vegetated habitats, the need for habitat protection, and refers to the mitigation potential of habitat protection. It also discusses restoration, creation and maximizing carbon uptake and storage of coastal ecosystems and highlights complexities in defining effectiveness of these mitigation actions, concluding that the overall potential to mitigate climate change is low (0.04 to 0.05 $\mathrm{Gt} / \mathrm{y})$ or $<0.5 \%$ of $10 \mathrm{Gt} / \mathrm{y}$ of anthropogenic emissions from all sources.

This paper expands the discussion of the role of Blue Carbon in climate change mitigation strategies by focusing on the importance of conserving existing marine pathways of carbon fixation, transport, burial and sequestration, and highlighting the challenges associated with the measurement, valuation, management, and governance of carbon in coastal, open ocean, and deep-sea ecosystems. Section Ecological and Economic Aspects of Blue Carbon identifies the carbon sequestration services provided by these ecosystems. Section Management of Blue Carbon for Sustainable Economies highlights how valuing ecosystem services (ES) can support release of financial resources from the private sector to help develop markets around the protection and regeneration of blue carbon, nature-based solutions, and Section Conclusion concludes with policy recommendations.

\section{ECOLOGICAL AND ECONOMIC ASPECTS OF BLUE CARBON}

As Blue Carbon becomes a center of focus for research and policymakers, improvement is needed in our ability to measure rates and permanence of carbon sequestration (Macreadie et al., 2017). Anthropogenic threats to the integrity of Blue Carbon stocks, defined here as carbon sequestered in the ocean, were not fully addressed by the SROCC. These threats, however, must be identified and weighed against the advantages of protecting these carbon draw-down systems so as to develop a sustainable economy. So far, governments, local communities and private sectors have worked with little cohesion, but once Blue Carbon ecosystems are clearly defined and their social and economic vulnerabilities to anthropogenic change are pinpointed in IPCC reports, they can then be harnessed to work in tandem toward sustainable goals to mitigate the socio-economic costs and ecological impacts of a changing climate. The following sections identify the potential for incorporating Blue Carbon in mitigation and carbon conservation strategies from both an 


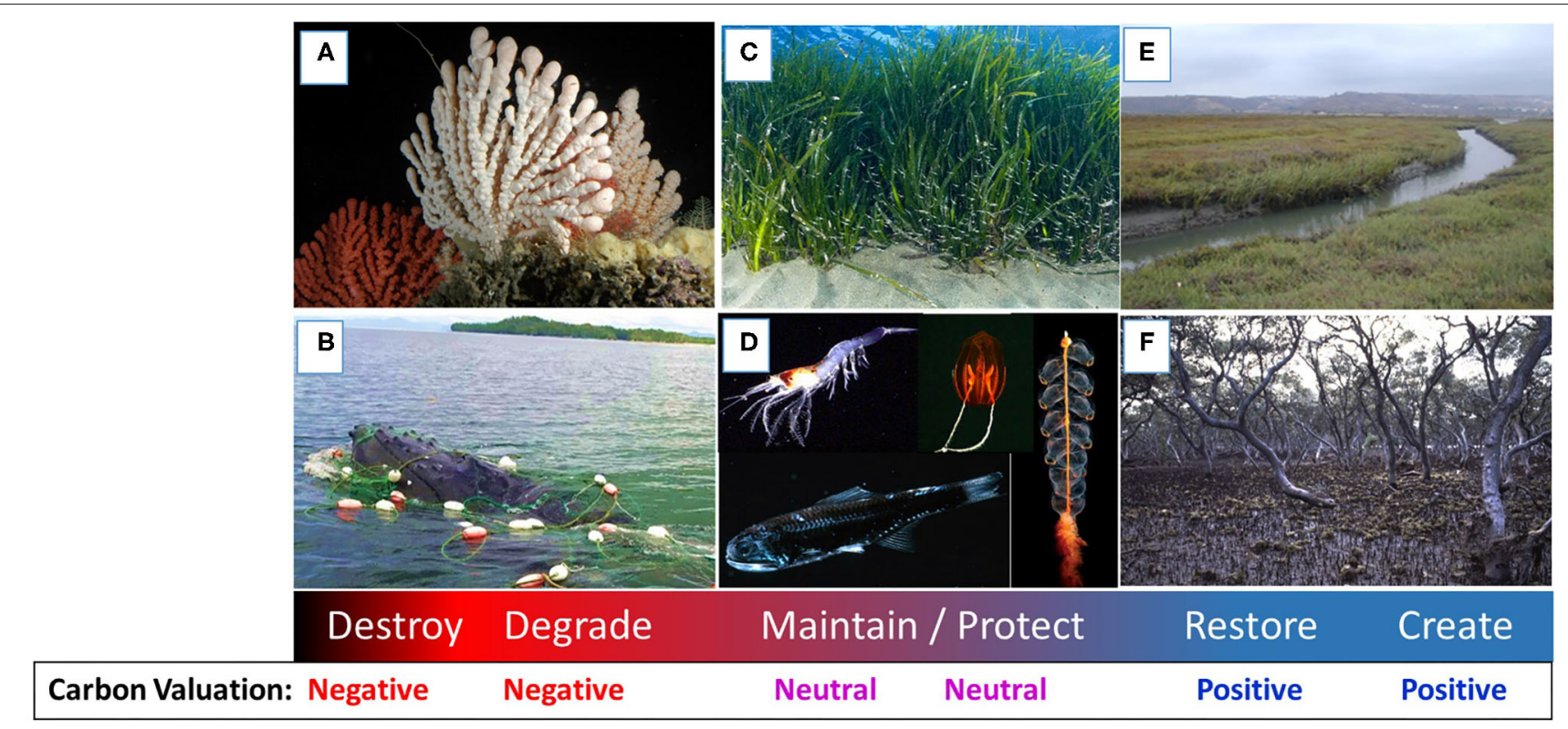

FIGURE 1 | Examples of ecosystems and processes along a gradient of actions that can have negative, neutral or positive effects on carbon storage. (A) Demersal fishing gear has destroyed many ancient deep-sea coral reefs in the past 30 years, and none have been restored (photo credit JAGO-Team/IfM-GEOMAR). (B) Whale populations have been decimated by hunting, ship strikes or entanglement in plastic fishing nets, lowering their ability to transfer carbon from the surface ocean to the deep-sea. (C) Seagrass beds can store large amounts of carbon but have been in decline worldwide, requiring protection for those that remain (credit C Vasapollo). (D) Pelagic animals such as mesopelagic fish draw carbon down from the shallows to great depths, their populations need to be maintained to protect this ecosystem service. Coastal developments have removed most saltmarshes $(\mathbf{E})$ and mangrove forests $\mathbf{( F )}$ worldwide, requiring efforts to restore or recreate these important natural carbon stores.

ecological and economic standpoint to help design sustainable management frameworks.

\section{Blue Carbon Ecosystems and Their Functions \\ Coastal Ecosystems}

The term Blue Carbon was coined a decade ago to describe the disproportionately large contribution of coastal vegetated ecosystems to global carbon sequestration and the need to protect these resources (Macreadie et al., 2017). Mangrove forests, saltmarshes and in some cases, seagrasses, build up large stocks of organic carbon in the coastal zone as they grow in depositional soils. Carbon storage in the soils of marine angiosperm (higher plant) habitats can be up to $1,000 \mathrm{tC} \mathrm{ha}^{-1}$, much higher than most terrestrial ecosystems (IPCC, 2019). Rising atmospheric $\mathrm{CO}_{2}$ levels are causing ocean acidification, but the increased amount of $\mathrm{CO}_{2}$ in seawater can stimulate photosynthesis helping to remove carbon from the seawater (Wada et al., 2021). Hence, another benefit of conserving submerged Blue Carbon habitats is that they may ameliorate ocean acidification locally (Su et al., 2020).

Increasing population densities and urbanization of coastal areas has damaged vegetated coastal habitats worldwide due to the impacts of fisheries, aquaculture, pollution and sedimentation (Gullström et al., 2021). Around 62\% of mangroves worldwide were destroyed between 2000 and 2016 (Goldberg et al., 2020), there has been about a $90 \%$ loss of salt marsh ecosystems (Gedan and Silliman, 2009) and seagrass carbon stocks are declining in various regions of the world (Waycott et al., 2009). When these blue carbon stocks are damaged, they may switch from sinks to sources of $\mathrm{CO}_{2}$ and of methane $\left(\mathrm{CH}_{4}\right)$ to the atmosphere, a much more potent greenhouse gas (Hiraishi et al., 2014; Macreadie et al., 2017; Vanderklift et al., 2019). Even without damage, some coastal wetland systems may emit significant methane and nitrous oxide, thus additional research is needed on how to manage coastal ecosystems for maximum carbon sequestration benefits (Rosentreter et al., 2021). Ocean warming affects the ability of marine systems to remove $\mathrm{CO}_{2}$ from the atmosphere because warmer waters absorb less $\mathrm{CO}_{2}$ and because it is a stressor for cool water vegetated marine habitats. For example, kelp forests in the warmest part of their NE Atlantic distribution store around $70 \%$ less carbon and release $50 \%$ less carbon than populations in the cooler parts of their distribution (Pessarrodona et al., 2018). Marine forests of kelp and fucoid seaweeds are being lost globally at their low latitude boundaries due to marine heatwaves and the gradual warming of surface seawater temperatures combined with human- induced stressors (Merzouk and Johnson, 2011; Kletou et al., 2018; Bernal-Ibáñez et al., 2021).

The SROCC report (IPCC, 2019) made clear that the maximum mitigation benefits of mangrove, seagrass and saltmarsh restoration is unlikely to reach more than $2 \%$ of current total $\mathrm{CO}_{2}$ emissions, but improved protection and management 
of these critical habitats would have multiple benefits. These include providing storm protection, improving water quality, benefiting biodiversity and fisheries as well as reducing carbon emissions from these ecosystems (Windham-Myers et al., 2018). The SROCC report did not fully address the importance of Blue Carbon sources and sinks beyond marine angiosperm habitats. For example, these habitats export carbon into the open ocean, so measurements of the rate of carbon build up in angiosperm habitats may underestimate the role they play in carbon sequestration (Santos et al., 2021).

Beyond Blue Carbon hotspot habitats, carbon is also stored in marine animals, so fish taken out of the sea contribute to Blue Carbon release (Mariani et al., 2020). Bottom trawled fishing gear damages ancient Blue Carbon stores such as rhodolith/maerl beds in seafloor sediments (Riosmena-Rodriguez et al., 2017) and is estimated to release a gigaton of $\mathrm{CO}_{2}$ from seabed sediments each year, equivalent to the entire aviation industry's annual emissions to the atmosphere (Sala et al., 2021). In sandy sediments, bottom fishing kills organisms that regulate carbon cycling on the seafloor (Hale et al., 2017), whereas in mud habitats it also releases carbon stored in the sediment itself (Sciberras et al., 2016). Bottom trawling also decreases the flux of organic carbon from shallow coastal waters to the deep sea by over $60 \%$ in North Western Mediterranean waters (Pusceddu et al., 2014; Laffoley, 2020).

\section{Open Ocean Ecosystems}

The ocean has dissolved carbon stocks that are at least an order of magnitude greater than those in global terrestrial soils. Most of this dissolved carbon is bicarbonate with an ocean residence time of around 100,000 years (Millero, 2007). Oceanic dissolved organic carbon is nearly equal to atmospheric $\mathrm{CO}_{2}$ and about 200 times the amount of carbon found in living marine biomass (Worden et al., 2015). Marine phytoplankton are responsible for $\sim 50 \%$ of global primary production $(\sim 50$ Gt C/year), these photosynthetic algae and bacteria fix dissolved inorganic carbon which is then mainly consumed and stored in the biomass of other organisms. The amount of carbon that is fixed by phytoplankton and then sequestered varies regionally and temporally, depending on surface water productivity, grazing/microbial degradation, and physical processes such as turbulence (Barnes et al., 2020; Briggs et al., 2020).

Most of the carbon fixed by phytoplankton is grazed by zooplankton although viral attack can also release their organic material which is then broken down by other microbes (Breitbart et al., 2018) generating particulate and dissolved organic matter, some of which will end up in deep water masses. The microbial breakdown of organic carbon produced by phytoplankton sequesters nearly 0.2 Pg C/year into the deep sea (Legendre et al., 2015 ) and around $30 \%$ of the organic particles from the sunlit ocean are exported below the mesopelagic zone (Briggs et al., 2020). The rates of sinking and degradation of carbon from phytoplankton are affected by cell size, morphology and chemical composition (Bach et al., 2019; Richardson, 2019). Fecal pellets, exoskeletons, dead animals and the vertical migrations of open ocean animals also transport the carbon from phytoplankton into the deep sea (Barnes and Tarling, 2017; Boyd et al., 2019).
Ocean warming and acidification are projected to slow sinking of particulate organic carbon to the deep seafloor by about $10-15 \%$ by the end of this century under a high $\mathrm{CO}_{2}$ emission scenario due to a projected decrease in primary production (Bindoff et al., 2019) and a community shift toward phytoplankton with smaller cells (Flombaum et al., 2020). There is uncertainty in this projection and so research into open ocean carbon sequestration rates is needed to locate and understand hotspots of open ocean carbon sinks (Gattuso et al., 2018; Buesseler et al., 2020; Jin et al., 2020; Martinetto et al., 2020).

Over the past 6 years macroalgae in the genus Sargassum has bloomed in open ocean areas of the North Atlantic and Caribbean. This has ended up in massive quantities on beaches with negative impacts on tourism, human health and coastal ecology (Van Tussenbroek et al., 2017; Resiere et al., 2018; Chávez et al., 2020; Gouvêa et al., 2020; Landrigan et al., 2020). Dealing with this has been expensive, Mexico, for example, declared a state of emergency and spent \$17 million in 2018 to remove 500,000 tons of Sargassum from its Caribbean beaches (Landrigan et al., 2020). Others have suggested Sargassum as a source of food or food additives (Amador-Castro et al., 2021; Choudhary et al., 2021), clean energy (AmadorCastro et al., 2021) and fertilizer (Thompson et al., 2020), or a local antidote to ocean acidification in bivalve culture (Han et al., 2020).

Sargassum (floating and attached to the seafloor) occurs in such large quantities globally (13.1 $\mathrm{PgC})$ and covers such vast areas $\left(445.54 \times 10^{4} \mathrm{~km}^{2}\right.$ ) (Gouvêa et al., 2020), that its carbon sequestration capacity has drawn attention globally (KrauseJensen and Duarte, 2016; Hu et al., 2021; Santos et al., 2021) and regionally (e.g., Korea-Sondak and Chung, 2015), but with conflicting perspectives. Hu et al. (2021) suggest that the C fixed and stored in Sargassum in the North Atlantic (6 M tons $/ \mathrm{mo}$ ) represents $<0.2 \%$ of phytoplankton storage, and is not globally significant, although it may have local importance. About $10 \%$ of the surface production of Atlantic Sargassum reaches the deep seafloor as particulate organic matter, but massive episodic inputs can occur during storms (Krause-Jensen and Duarte, 2016). Wild Sargassum growth and sinking has been proposed as a natural analog of basin-scale seaweed farming (afforestation), one method of enhanced carbon dioxide removal under consideration, because it involves scales that are orders of magnitude larger than feasible pilot studies. However, Bach et al. (2021) suggest that nutrient reallocation (from phytoplankton to Sargassum) and calcification by encrusting marine life reduce the net carbon dioxide removal efficiency of Sargassum by $20-100 \%$ and that increased ocean albedo of Sargassum could have a larger effect on climate radiative forcing than Sargassum removal.

\section{Deep-Sea Ecosystems}

Dissolved organic carbon is $\sim 70 \%$ of the total organic carbon in the ocean, and most of this is found at depths $>1,000 \mathrm{~m}$ where this carbon remains out of contact with the atmosphere for thousands of years (Hansell et al., 2009). Mesopelagic zooplankton and fish typically migrate large distances each day to optimize their own feeding and to avoid predators and this plays a major role in transporting carbon down from surface waters 
(Davison et al., 2013; Steinberg and Landry, 2017; Kiko and Hauss, 2019). Deeper water fish then transfer carbon into longterm storage below 1,000 $\mathrm{m}$ depth (Trueman et al., 2014) where most of this carbon remains sequestered from the atmosphere for thousands of years. This has led to suggestions to grow and deposit macroalgae in deep water (Duarte et al., 2017; Queirós et al., 2019) as well as rebuild stocks of marine vertebrates (Martin et al., 2016; Smale et al., 2018). There is also interest in conserving processes that transport carbon into deep water e.g., vertically migrating mesopelagic krill or calcifiers that provide ballast (Howard et al., 2017b). As in shallow waters, carbon can be sequestered via passive burial in sediment or by active bioturbation (Atwood et al., 2020). The carbon stocks in the top $1 \mathrm{~m}$ of seafloor sediments $(3,117 \mathrm{Pg})$ are more than twice that of terrestrial soils (Atwood et al., 2020).

Rising bottom temperatures or shifting of warm currents could increase the release of carbon stored in buried methane hydrates on continental margins (Ruppel and Kessler, 2017). Chemosynthetic ecosystems, and methane seeps, in particular, sequester carbon compounds emitted from within the Earth's crust (Thurber et al., 2014). Microbes convert methane into carbonate on the seafloor and also make this carbon source available to animals as symbionts. Ocean warming may dissociate more methane, and if this occurs, ensuring it never reaches the atmosphere takes on added importance. This sequestration service has never been subject to monitory valuation or even justified seep conservation, but the potential for novel $\mathrm{CO}_{2}$ and $\mathrm{CH}_{4}$ removal mechanisms of potential climate remediation value has been recognized (e.g., Diaz-Torres et al., 2015; Mahon et al., 2015).

Just as trawling releases carbon from shelf and slope marine sediments, deep-seabed mining (which has yet to occur) could release carbon sequestered in sediments, although some of this material would still be in waters $>1,000 \mathrm{~m}$ deep and not released to the atmosphere. In the case of mining of polymetallic nodules, the carbon content of these sediments is very low as they occur below oligotrophic waters and so the risk of releasing carbon to the atmosphere is likely to be small (Levin et al., 2020). This may not be true on organic-rich continental margins (e.g., areas targeted for phosphate mining), where remineralization could stimulate more phytoplankton production (Atwood et al., 2020).

The ocean plays a critical role in global climate regulation through uptake and storage of heat and carbon dioxide. However, this regulating service causes warming, acidification and deoxygenation and leads to decreased food availability at the seafloor (Levin and Le Bris, 2015; Sweetman et al., 2017). These changes are likely to affect the productivity, biodiversity and distributions of deep-sea fauna, thereby compromising key ES (Mora et al., 2013; Sweetman et al., 2017; Morato et al., 2020). Limited information on deep-sea species thresholds, tolerances and tipping points for various climate drivers means that predictions of risk, vulnerability and responses are difficult to make, and confidence is low. To date, the most knowledge involves projected changes in biomass in response to declining surface productivity and POC flux (Yool et al., 2017; Jones et al., 2018; Bindoff et al., 2019).

\section{Policy Implications Beyond Carbon Benefits}

Coastal ecosystems are by definition a highly active interface between human and natural infrastructures which is exposed to a number of potentially threatening human activities. These activities include aquaculture, fisheries, coastal tourism, coastline development/habitat degradation and waste-water discharges which accompany growing human density on coastal shelves. Such impacts have recently been shown to have long-term deleterious effects such as the decrease of tidal marsh carbon sediment stocks due to human reclamation (Ewers-Lewis et al., 2019). While the active integration of Blue Carbon ecosystems into sustainable policy frameworks supports natural $\mathrm{CO}_{2}$ entrapment, it also could allow for indirect monitoring of these anthropogenic disturbances.

Coastal Blue Carbon ecosystems also present a key advantage by supplying multiple ecosystem services (ES) in addition to carbon sequestration, upon which climate and population security might rely (Windham-Myers et al., 2018; Duarte et al., 2020). Key ES provided by coastal carbon ecosystems include protection of coastal habitats which serve as feeding and nursery grounds for fish and shellfish, protection of coastal infrastructure (for transportation, communication, dwelling, energy etc.) from storm surge and flooding as well as provision of water filtration. These ES are crucial for vulnerable communities that live near the shoreline or rely heavily on resources from these ecosystems ${ }^{1}$. Connectivity between ecosystem services is a key challenge to policymakers along with site- and species-specific requirements. Although providing $<1 \%$ of global GHG, small islands are highly exposed to problematic impacts of climate change: changing temperatures, $\mathrm{OA}$, weather disturbances are some of the many (Wilson and Forsyth, 2018). Viable policy frameworks which incorporate Blue Carbon ecosystems can mitigate climate change conflicts by sustainably using carbon ecosystems to support vulnerable communities, a method known as ecosystem-based adaptation (EbA) and a type of naturebased solution (NbS). Nature-based Solutions contribute to climate change mitigation on 3 fronts: reduction of GHG emissions, carbon capture and storage and socio-economic benefits of mitigation strategies (Raghav et al., 2020). They can physically shield communities effectively and can be a key resource for survival: wetlands not only mitigate the impacts of floods and storms but can also provide water which is naturally stored for communities in need. Attempts at replacing this protective service with man-made infrastructures have met with little success, high costs, and continuous ecosystem depletion.

\section{Assessing and Quantifying}

With the array of carbon ecosystems comes an array of processes by which carbon is sequestered from the medium from which it is extracted (let it be air or water). This service is too often poorly understood as there is both a flow of carbon passing through this natural machinery (through the

\footnotetext{
${ }^{1}$ https://www.worldbank.org/content/dam/Worldbank/document/EAP/Pacific $\% 20 I s l a n d s /$ climate-change-pacific.pdf
} 
process of sequestration) as well as carbon stocks in relevant ecosystems (Keith et al., 2021). The real absolute quantity of carbon trapped in ecosystems can thus be poorly accounted for if these two phases are not taken into consideration. Often younger ecosystems are given priority while key older ones are destroyed along with their carbon storage. In order to develop effective policies for climate change mitigation, carbon stock assessments ought to be considered (Gullström et al., 2021).

Carbon flow through open marine ecosystems is a cycle in which living components have dynamic movements. Thus, carbon accounting must also avoid underestimating the transfer of allochthonous carbon, which has by definition traveled from its source habitat. Policy has commonly focused on carbon ecosystems in isolation to facilitate management without taking this transfer from source habitats into account. A contribution to sustaining the sequestration of marine carbon is through the conservation of marine vertebrates who support this cycle by transferring carbon from surface to deeper waters (Smale et al., 2018).

\section{Monitoring and Protecting}

Once identified, carbon-sequestering ecosystems must be a point of focus for both mitigation and conservation efforts, whether on local, national or global scales. For example, with shorter sea-ice durations and higher surface temperatures, entire areas of the Antarctic seafloor are offering a new alleyway for carbon sequestration, currently with very limited anthropogenic disturbance, causing highly productive benthic communities (Fillinger et al., 2013). However, human exploitation must be kept to a minimum through international policy efforts that should stand firmly in the face of commercial industry interests which would seek to exploit this newly freed and somewhat pristine part of the Southern Ocean for living and non-living resources (Bax et al., 2020). Gogarty et al. (2020) propose "non-market" approaches to achieve some Paris Agreement goals in managing this new area. Market solutions that aim to highlight the value of regenerative natural systems can also be applied (Chami et al., 2019). Policies based on a similar thinking ought to also be applied to highseas and intertidal areas which are too often cast aside in MPA design.

While key ecosystems must be identified and protected, artificial mechanisms can also be used to support their impact on climate change mitigation. Negative Emissions Technologies (NET) might offer short-term mitigation, but their climate and environmental costs and benefits are yet to be ascertained for projects of sufficient scale to mitigate climate change. Only ocean fertilization has been reviewed so far and ascertained as ineffective in the short term (Williamson et al., 2012). Others include enhanced weathering, reforestation, bioenergy production with carbon capture and storage (BECCS), carbon fixing in soils as well as direct air carbon capture and sequestration (DACCS) which has the advantage of presenting less adverse impacts (Gambhir and Tavoni, 2019). However, these systems can be water and energy intensive and even require vast dedicated land over large timescales (with negative biodiversity effects), thus they must be approached with caution ${ }^{2}$. Similarly, any negative impact of these systems on key carbon ecosystems, a process known as "leakage," must be monitored and avoided (Ullman et al., 2013). NET are not alternatives for emission reduction or nature-based carbon conservation: they must imperatively be paired with strategies that protect carbonsequestering ecosystems ${ }^{2}$.

\section{Preserving and Restoring Carbon Sequestering Ecosystems}

According to Pendleton et al. (2012), emissions from the degradation of these ecosystems are equivalent to 3-19\% of deforestation worldwide and result in economic damages of around 6 to 42 billion US\$ annually. The degradation of coastal ecosystems each year releases between 0.15 and $1.02 \mathrm{Pg}$ (one billion tons) of $\mathrm{CO}_{2}$ into the atmosphere. Policy makers can shield key carbon cycles which are disturbed by anthropogenic activity through conservation frameworks. Although Marine Protected Areas (MPA) are growing at about 8\% per year (Worm, 2017), this protective system remains far too limited with below $3 \%$ of the global ocean being effectively protected. Ocean protection could yield several benefits alongside securing carbon stocks at risk from bottom trawling, such as supporting fisheries' yield and protecting biodiversity (Sala et al., 2021).

Once disturbed, some functions of these ecosystems can still be restored and maintained. As mentioned above, ES can ensure climate security for local communities and restoration of carbon ecosystems has the potential to optimize these benefits. For nations that are small greenhouse gas emitters, addition of Blue Carbon habitat may offset their emissions as contributions to the Paris Agreement, but this cannot substantially address the global greenhouse gas problem. However, once policy frameworks incorporate the challenges of restoration program (mainly continuous funding, site- and species-specific requirements and extensive time frames (Wilson and Forsyth, 2018), they can have vast positive impacts on both habitats and populations. The valuation of protecting and restoring coastal ecosystems not only creates financial incentives while attracting investor interest but can also entail long-term investments into community development. As Cziesielski et al. (2021) explain regarding Red Sea Blue Carbon ecosystems, policy design must require the involvement of different fields of expertise (financial, technological, sociological and ecological) in order to ensure optimal long-term economic benefits, social support and ecological conservation. This is the founding principle of a sustainable Blue Economy ${ }^{4}$. In the current world, the only way to design such policy actions is to understand the economic powers behind the scenes: $47 \%$ of factors constraining policy makers have recently been shown to be financial in nature (Beeston et al., 2020).

\footnotetext{
${ }^{2}$ https://easac.eu/fileadmin/PDF_s/reports_statements/Negative_Carbon/ EASAC_Report_on_Negative_Emission_Technologies.pdf

${ }^{3}$ https://mpatlas.org

${ }^{4}$ See https://www.worldbank.org/en/programs/problue.
} 


\section{MANAGEMENT OF BLUE CARBON FOR SUSTAINABLE ECONOMIES}

\section{Valuing Carbon Services Coastal Carbon}

Coastal marine ecosystems could provide as much as twothirds of the ecosystem services that make-up our planet's natural capital (Cantral et al., 2012). Nevertheless, these services have been neglected through inadequate management, misled governance and gaps in social and scientific knowledge along with lack of local knowledge. A study reported by Quevedo et al. (2021) documented that coastal ecosystem services are more likely to be acknowledged by a society which benefits directly from them; in other words, clearer pathways between ecosystem services and societies are key for populations to truly value an ecosystem as a whole. This explains partly why Pacific Island nations have been at the forefront of advancing ocean issues in climate policy. For example, Chami et al. (2020b), provide a value for the carbon sequestration services of the existing saltmarshes in England. They use estimates of the carbon sequestration of the remaining saltmarshes as well as their flood control services to derive a value of $\$ 4.7$ billion dollars. Sun and Carson (2020) quantified the value of storm protection from Gulf of Mexico wetlands at an average of $\$ 1.8$ million dollars per year per $\mathrm{km}^{2}$ (carbon sequestration services were not a part of this valuation). Recent discoveries in Red Sea mangrove forests suggest an underestimation of carbon sequestering potential due to the unaccounted-for positive impact of ocean acidification on the ocean's capacity to dissolve $\mathrm{CO}_{2}$ (Saderne et al., 2020), a process likely applicable for a number of key areas around the globe.

The economic value of ecosystem services is either determined from quantifiable resources directly derived from the ecosystem, a service which is vulnerable to disturbance or changes over time (Fisher et al., 2008), or from the cost of restoring these coastal habitats were destruction to occur (Garrod and Willis, 1999). Payments for ES aim to incorporate the socio-economic levels involved in ES valuation but are sensitive to the highly changeable market of carbon pricing as well as issues of accountability and governance (Börner et al., 2017). ES valuation has been criticized as it might overlook the complexity of the connectivity between services and non-pecuniary services of ecosystems regarding their aesthetics and importance in local culture (Kosoy and Corbera, 2010). This might shift the focus of authorities from long-term social and environmental benefits to mainly financial returns. This perception of ES value can also change with different stakeholders and from regional to global scale (Brown and Adger, 1994).

\section{Open Ocean Carbon}

From a welfare point of view, marine systems provide a regulatory carbon service with global impact. The Exclusive Economic Zones (EEZs) in the Mediterranean basin have been used to estimate the wider economic impact of marine carbon sequestration in this area (Canu et al., 2015). The results indicate that the Mediterranean Sea is a key global sink of $\mathrm{CO}_{2}$ with an estimated overall flux of $\mathrm{CO}_{2}$ of 17.8 millionton $\mathrm{CO}_{2} /$ year. The EEZs of Algeria, Greece, Italy and Spain represent $84 \%$ of the total carbon sequestration flows while covering only $56 \%$ of the total surface of the Mediterranean. However, heterogeneity and lack of information on carbon market prices as well as failure to recognize the co-benefits that these ecosystems generate have limited their integration into economic valuations. The absence of information on the real value of these ecosystems can lead to inefficient decision-making, often causing mismanagement (Canu et al., 2015). In addition, EEZs form the limit of the UNFCCC jurisdiction, leaving most of the open ocean and deep sea unconsidered with respect to climate mitigation and adaptation.

Moreover, the inclusion of social welfare variables in calculations of climate-change mitigating $\mathrm{BCP}$ impacts is now becoming key in policymaking related to open-ocean measures. Such regulations can also aim at minimizing the social impacts of carbon release. Hazards related to poor management of carbon sequestering ecosystems have both market and nonmarket consequences which need to be incorporated into cost-benefit weighing of Blue Carbon. The social cost of carbon (SCC) supports such cost-benefit evaluations of carbon emission mitigation policies. This process might be done using risk thresholds, independently from market-based economic impacts (Metcalf and Stock, 2017). Integrated Assessment models (IAMs), which so far only assess the risk of sea level rise, could present doubled levels of SCC with the inclusion of carbonrelevant ocean-related risks (Narita et al., 2020). SCC is included in the 5 "Shared Socioeconomic Pathways" (SSPs), scenarios weaved by outcomes of climate change, but needs to be adapted to SSPs which have a higher probability of occurrence (Yang et al., 2018).

\section{Deep Sea Carbon}

Only a handful of papers have considered the economic value of changes in ecosystem services in deep waters. The downward carbon flux at $1,000 \mathrm{~m}$ in the North Atlantic is projected to decrease by $27-43 \%$ under RCP 8.5 by 2,100 ; in the North Atlantic this is estimated to represent a loss of US $\$ 170-3,000$ billion in abatement (mitigation) costs and US \$23-401 billion in social costs (Barange et al., 2017). Others have highlighted the declining value of open ocean carbon sequestration in the eastern tropical Pacific (Martin et al., 2016) and, again, the Mediterranean (Canu et al., 2015). No economic estimates have been done in the direct context of ocean acidification in the deep sea. Surface waters are rapidly transported into the deep ocean and $\mathrm{CO}_{2}$ is definitely rising, with carbonate saturation state declining in some deep waters such as in the Arctic and North Atlantic (Gehlen et al., 2014; Sweetman et al., 2017; Sulpis et al., 2018; Bindoff et al., 2019; FAO, 2019), but the consequences for ecosystems and their services are poorly known (Bindoff et al., 2019). Ocean deoxygenation will likely impair fisheries resources (Rose et al., 2019) with some of the greatest effects occurring at bathyal depths where oxygen minimum zones are expanding. Impacts of climate change are also expected to enhance carbon sequestration in key areas such as the Arctic and the Antarctic, where the decrease in ice will provide vast areas for carbon capture and longer blooms allow increasing sequestration in the Southern Ocean (Barnes and Tarling, 2017; Bax et al., 2020). 


\section{Shifting Our Markets}

\section{The Role of Natural Capital Valuation}

Only an estimated 3\% of current climate finance is allocated to nature-based solutions (NbS) (Raghav et al., 2020). Attracting the attention of the private sector provides opportunities to create sustainable business models that include social responsibility in order to invest in current carbon storage to comply with Paris agreements. Similarly, investment in natural climate solutions can support local communities and their ecosystems alike. Within carbon markets, buyers of Blue Carbon credits could choose to finance projects in areas that support their supply chain. For example, seafood companies might invest in the protection or restoration of Blue Carbon ecosystems for reasons beyond carbon offsets, such as co-benefits like nursery habitat protection of harvested species, protection from extreme events, mitigation of erosion and salinization, and improvement of human livelihoods (Vanderklift et al., 2019). In a situation of uncertainty, such approaches can be called low- or no-regret, as their cost is relatively low and they would provide benefits with or without expected impacts of climate change (Gattuso et al., 2018). The no-regret approach can be used at different social levels (households, communities, and local, national and international institutions) in order to increase resilience of social, economic and environmental policy benefits. However, these frameworks and their associated benefits are often poorly quantified, limiting investment. Providing information on the associated benefits of Blue Carbon can help increase financing for climate action while new resources flow in Siegel and Jorgensen (2011) and Ullman et al. (2013).

Protection and restoration of highly productive Blue Carbon coastal ecosystems may guarantee first, the integrity of carbon storage and second, the long-term removal of greenhouse gases from the atmosphere. It still remains challenging to trace the carbon sequestered back to its source and enhanced sequestration at the sink site needs to be assessed using management actions in source habitats (such as macroalgae). This cost-benefit approach common in financial investments can be used here to protect, invest in, and ultimately put these ecosystems on a sustainable path. But while the cost of conservation is well-understood and readily quantified, understanding the benefits of a vibrant natural world to our health and economic well-being depends on being able to show how natural resources, including species, habitats, and biodiversity, provide tangible value to humans (Chami et al., 2020a; Dasgupta, 2021). If we can reliably identify and measure the market-value of all the services provided by natural resources-such as carbon sequestration, flood control, fisheries support and more-we can then compare the present monetary value of these benefits with the cost of investing in them, just as we do for other financial assets. An example of such an approach is provided by Chami et al. $(2019,2020$ a) who apply financial valuation methods to value market services provided by cetaceans such as great whales in Chile and Brazil. Using existing markets and prices they derive an average lifetime value of $\$ 2$ million per whale from carbon sequestration, whale tourism as well as impact on fisheries services. Their financial estimations use a growth model (logistic model in the case of cetaceans) and rely on the EU ETS to pin down the carbon price of $\$ 24.42$ in
2019. By conserving these species, there is a potential to maintain an ongoing carbon sequestration pathway which is potentially vast compared to other designated ecosystems. Conservation efforts targeting these species can thus be fuelled by the carbon sequestration cycle in each individual along with their natural market services.

\section{What Does the Valuation of Natural Capital Serve?}

The resulting valuations can be quite effective at motivating environmental investment for several reasons. First, they show exactly what concrete services society currently receives from our stock of natural resources, which helps the public understand the relevance of these resources for its daily life. In addition, expressing the benefits of preserving natural resources in monetary terms allows for a dollar-to-dollar cost-benefit comparison, which is important as people are more comfortable making decisions when the stakes are expressed in financial terms. And finally, the value embodied in these natural assets can be very large-not only justifying the cost of preserving them, but also causing surprise and capturing the imagination of people who learn about the valuations. Behavioral economics research shows that people are more likely to purchase products or make investments that inspire these feelings (Chami et al., 2020b).

Valuing the benefits of ecosystem services highlights the cost of doing nothing, or no-action, related to degradation of ecosystems. In an estimation of global ES, Costanza et al. (2014) point out that the loss of ES between 1997 and 2011 due to land change lies between $\$ 4.3$ and $\$ 20.2$ trillion/year in 2007 $\$$ US. The core of restoration programs lies in our ability to quantify the value of Blue Carbon sequestration-also considering large uncertainty about methane emissions (Rosentreter and Williamson, 2020)-which would lead to the acquisition of carbon credits by countries investing in the calculated restoration of specific coastal ecosystems with high carbon potential (Kroeger et al., 2017; Tang et al., 2018).

Climate change, which jeopardizes the future and well-being of entire populations (Thiébault and Moatti, 2016), must be tackled through the combination of several approaches: (1) having a clear understanding of stakeholders' responsibilities for the management and governance of sensible ecosystems (either local community, industries, governmental institutions and international frameworks such as Regional Fisheries Management Organizations and the Convention on Biological Diversity), and (2) outlining a clear methodology to value carbon stocks, so as to identify key ecosystems which must be either restored or sustainably managed (Howard et al., 2017a,b). Scientific research can fuel those strategies as we enter the Decade for Ocean Science for Sustainable Development upon which future mitigation actions are likely to rely (IOC-R, 2021). Sustainable management of carbon sinks (and the local communities which can benefit from them) will also help nations meet their climate mitigation commitments. These include pledges taken under the umbrella of Nationally Appropriate Mitigations Actions (NAMAS), especially relevant in rapidly evolving coastal ecosystems that are vulnerable to abiotic variations such as temperature increase, extreme events (e.g., marine heatwaves), and sea-level rise (Laffoley and Grimsditch, 
2009; Kirwan and Mudd, 2012; Gallo et al., 2017; Strydom et al., 2020). A stricter approach to climate change mitigation using the full potential of Blue Carbon across a range of ecosystems will rely on international cooperation, as suggested by the G20 Task Force 2 Policy Brief by Mansouri et al. (2020).

\section{Governance}

\section{Financing}

According to OECD (2016), a Blue economy would be able to create $\$ 3$ trillion annually in gross value added by 2030 . Blue growth is based on protection, conservation and investment in Blue natural capital, which, in turn, would lead to economic growth, but some aspects include highly destructive and climateimpairing practices like oil and gas extraction, or seabed mining. Cziesielski et al. (2021), challenged the traditional model of business-as-usual in which all sectors are interconnected but mainly related to the environment through exploitation. In their economic model, the environment (sustainably managed) was placed as the focal point of strategic development and other sectors (industry, communication, education, etc.) as secondary branching points. This method shows that the success and failure of each sector directly influences and impacts the environment, along with itself and others; in other words, the environmental sector is effectively "the core of social and economic wealth." In the ocean's case, the High Level Panel for a Sustainable Ocean Economy (Ocean Panel) showed that 1 USD invested in actions linked with a Blue economy could generate 5 USD in global benefits (Konar and Ding, 2020). Then a key question must be formulated: How do we find this metaphorical "first" dollar, and thus initiate a productive and virtuous circle?

Direct and indirect public financing from international and regional organizations, states and local authorities can take the form of subsidies, grants, loans and transfers (international public aid) (Levallois, 2020). However, these modalities are mainly coming from general fiscal budgets, for which matters depend on public decision and are highly vulnerable to discretion and competing priorities of decision-makers. In this regard, the panorama of specific affected taxes going to ocean conservation still have extensive margins for improvement. Some examples exist but would need to be generalized to predict a scaled impact. For instance, in France, the owners of leisure boats are paying a yearly tax called "francization," related to the "Conservatoire du Littoral, 2020" for protecting coastlands (buying vulnerable lands, implementing ecologic restoration, projects against erosion, etc.). This tax is paid by more than 7 meter long boats, which are relevant targets related to coastal impacts (i.e., source of disturbance for Posidonia carbon sinks for instance), with low elasticity and a significant capacity to pay compared to the general population. This system gathers around 37.5 million euros/year, representing $72 \%$ of the institution's annual budget (51.7 million in 2020, according to the annual report of the "Conservatoire du Litoral").

It might be relevant to replicate these financial mechanisms for marine carbon conservation (both open ocean and deep sea) along with other targets. For instance, part of the product of existing port taxes could be dedicated to Blue economy investments. Even at low rates, the spectacular increase in sea traffic in the past decades and its associated impacts present increasingly important opportunities for financing (cruises, commercial, transport, tankers, etc.). In other terms, the reduction of the added value of highly pollutant activities allows for reinvestment in the Blue economy, "re"-creating sustainable added value. In any case, this framework would call for coordination between ports, cities and nations, through a highly competitive economy. A regional approach would be relevant to pilot activities before upscaling (for instance European ports in the Mediterranean Sea). Market-based responses and private financing (compensation of private companies, financial markets) can also be incentives to develop private "voluntary" participation in such investment efforts.

For example, carbon markets have arisen along with carbon pricing, a global trend triggered by increase in atmospheric $\mathrm{CO}_{2}$ and in the destruction of carbon sinks. As Boyce (2018) explains, carbon pricing can be a challenging exercise: "carbon pricing initiatives around the world today cover approximately 8 gigatons of carbon dioxide emissions, equivalent to about $20 \%$ of global fossil energy fuel emissions and $15 \%$ of total $\mathrm{CO}_{2}$ equivalent greenhouse gas emissions." Moreover, these markets are highly volatile, which poses a challenge for smallscale projects relying on coastal carbon returns. Hence, carbon pricing can either be through Emissions Trading Schemes (ETS), which facilitate the trade of permits for greenhouse gas emissions by capping the total level of emissions allowed; or carbon taxes, which set a price on carbon itself (The World Bank, 2019). Cabon pricing discourages emissions (Fankhauser and an Jotzo, 2018) and gives incentives to households, firms and governments to choose a more cost-effective way to reduce emissions (Boyce, 2018).

Carbon emissions from the degradation of coastal ecosystems such as mangroves, seagrasses, and saltmarshes, however, are rarely included in emissions accounting or carbon regular markets and protocols. In order to promote Blue Carbon projects in regulated carbon markets, reliable financial analyses must be taken into account to estimate Blue Carbon offsets, along with predictions of survival rates of new or restored vegetation in Blue Carbon ecosystems and measures of additional risks and benefits that could impede or enhance income flows (positive and negative externalities). In other words, a reliable scientific analysis of the permanence of these ecosystems must be carried out in order to guarantee that carbon is sequestered for long periods of time (from 25 to 100 years), without ecosystem degradation (Thamo and Pannell, 2016). These scientific efforts include research on natural sequestration and degradation of Blue Carbon ecosystems, impacts of human activity on the carbon cycle, exchanges of carbon between terrestrial and ocean ecosystems, the development and advocacy of sustainable policies, the creation of protection protocols as well as economic analyses of Blue Carbon impacts (IOC$R, 2021)$. Such an all-rounded approach can support existing and emerging carbon markets while calling for key ecosystem conservation and atmospheric carbon reduction. Limiting loss of coastal ecosystems may be more beneficial than implementing extensive restoration efforts in regions with lower carbon benefits (Pendleton et al., 2012; Vanderklift et al., 2019). This 
is particularly relevant as the carbon sequestration potential of coastal ecosystems such as mangroves is often underestimated since it is based on measuring methods used for terrestrial ecosystems which do not account for root and soil sequestration potential. A recent valuation project in Cispatá, Colombia, which covers 29,000 acres of mangroves aims to include the entirety of the carbon potential of this ecosystem as carbon credits which would differ from usual forestry credits both in their pricing potential and their management requirements for a reliable market (Klein, 2021).

\section{Management}

Strategies for sustainable management of Blue Carbon ecosystems can be based on their potential for adaptation and/or carbon sequestration. Adaptation plans are based on other services provided by Blue Carbon ecosystems such as protection from storm damage and flooding and the provision of resources, and the co-benefits that arise from them. Nationally Determined Contributions (NDCs) under the Paris Agreement provide a framework for declaring climate change mitigation intent which must be revised and enhanced every 5 years. Ocean adaptation is seen more clearly in the initial NDCs across the globe than carbon sequestration (Gallo et al., 2017): adaptation plans are found in $39 \%$ of parties with coastal wetland ecosystems whereas sequestration specific to coastal ecosystems is currently incorporated in the NDCs of only $19 \%$ of the relevant parties (Herr and Landis, 2016). Synergy between climate adaptation and mitigation strategies within NDCs provides an optimal approach for Blue Carbon ecosystem management. With the inclusion of carbon sequestration as an economic asset, wellrounded management planning for marine resources can benefit both a country's carbon emission mitigation strategy and its economic framework.

Recognition of Blue Carbon benefits are growing in the ocean policy community. Of the 47 submissions to the UNFCCC Ocean and Climate Change Dialogue held Dec. (2020) 85\% of these referenced Blue Carbon, with an average of 7 mentions per submission that did, and greater intent among non-state submissions $(89 \%)$ than state submissions $(80 \%)^{5}$. The Blue Carbon initiative, coordinated by Conservation International, the Intergovernmental Oceanographic Commission and IUCN (and supported by the International Blue Carbon Scientific Working Group), strives to build Blue Carbon into NDCs, REDD+ (Reducing Emissions from Deforestation and forest Degradation), National Management plans and financing mechanisms such as the Green Climate Fund.

Blue Carbon mitigation efforts benefit from being incorporated into national strategies. In Madagascar, voluntary carbon markets, known to be better adapted for smallerscale projects, are used across several project sites ${ }^{6}$. While legal regulations are being put into place to integrate coastal area management into national biodiversity plans (Decree $\mathrm{N}^{\circ}$ 2010-137) (Commission Nationale de Gestion intégrée des

\footnotetext{
${ }^{5}$ Dobush, B.-J., Gallo, N. D., Guerra, M., Guilloux, B., Holland, E., Seabrook, S., et al. A new way forward for ocean climate policy as reflected in the unfccc ocean and climate change dialogue submissions. climate policy. (in revision).

${ }^{6}$ see https://blueventures.org/conservation/blue-forests/.
}

mangroves) (Herr et al., 2017). International policies such as REDD+, a program that compensates landowners for evident reductions in forest-based carbon emissions, incentivize the integration of coastal ecosystem restoration plans to a country's national climate change mitigation strategy. However, the incorporation of Blue Carbon plans into REDD + activities will depend on a country's definition of forest ecosystems (Herr and Landis, 2016). Similarly, wetland inclusion is encouraged but not mandatory in the 2006 IPCC guidelines for National Greenhouse Gas Inventories despite the advantages of including coastal ecosystems in a country's greenhouse gases inventories ${ }^{7}$. Thus, heterogeneity in NDC commitments to Blue Carbon management has made worldwide policymaking challenging (Laurans et al., 2016). As explained by the Blue Carbon and NDC Guidelines developed by the Blue Carbon initiative ${ }^{8}$, ecosystems can benefit NDCs by adding to the national green house gas emission mitigation strategies, providing ecosystem services to benefits local areas and communities, fuelling NDC achievements during the 5-year period, encouraging crosssectorial efforts on the coasts to reach NDC goals (particularly in NDCs which incorporate Coastal Zone Management) and supporting Sustainable Blue Economies.

NDC inclusion of coastal ecosystems also encourages external financial support and climate finance for their sustainable management ${ }^{2}$. Coastal ecosystems need to be a part of a country's economic framework. A distinction among ecosystems during valuation calculation is important because certain habitats (e.g., seagrass meadows) can be expensive systems to restore (Bayraktarov et al., 2016). On the other hand, some vegetated coastal habitats have adaptive abilities and restoration capacities that could be invested in at minimal costs (Gedan et al., 2011; Duarte et al., 2013). This allows for strategies that relate to the maintenance of particular ecosystems such as the removal of anthropogenic nutrients in coastal habitats, the control of bioperturbator populations and the restoration of hydrology to increase carbon accumulation (Macreadie et al., 2017). These strategies include land-management regulations such as "other effective area-based conservation measures" (OECMs) which co-benefit biodiversity conservation under the umbrella of sustainable area management (Kalinina et al., 2021). Such restoration programs can also offset sequestered carbon losses due to damages, if properly managed, via processes of ocean zoning and marine spatial planning (Irving et al., 2011). Greiner et al. (2013) explain in their evaluation of the role of seagrass Zostera marina that restored meadows could accumulate quantities of carbon similar to a pristine one, given about a decade. Their 2011 social cost estimates are $\sim 7,000 \$$ per year of carbon storage provided by restored meadows (Greiner et al., 2013). Hejnowicz et al. (2015) however arrived at higher estimates, using the cost of planting, monitoring, contracting and government oversight over the long term.

Despite recent developments in international policies regarding the protection of marine resources for climate change mitigation, results will only be achieved if there is ownership by

\footnotetext{
${ }_{7}$ https://www.ipcc.ch/report/2006-ipcc-guidelines-for-national-greenhouse-gasinventories/

${ }^{8}$ See https://www.thebluecarboninitiative.org.
} 
local actors. Legal and territorial planning frameworks, including social responsibility, must be defined on coastal compensation sites (Thamo and Pannell, 2016). This territorial perspective on governance might integrate potentially contradictory points of views but must define joint common responses. Examples include the 2020 Earth Security report on Mangrove financing, presenting a case for investment in mangrove restoration using a network of 40 key cities which can focus on mangrove protection while carbon markets evolve to reach global importance. This requires integration of information and data across institutions (on national levels as well as local representation of ministries), along with the coordination of local authorities and participation of communities and economic stakeholders in public decision. Adequate realistic planning involving local partners will facilitate measuring benefits and define priorities for conservation and/or restoration, and implement concrete activities to achieve results... if sustainable financing is available. On the one hand, financial incentives for carbon compensation are able to attract short-term funds but are not necessarily adapted to local expectations and remain lacking in local knowledge and input. Territorial planning with a community perspective can be adapted to local needs, becoming an efficient source of long-term development, but lacking in economic power. These often-opposing approaches would warrant the role of public institutions to foster dialogue and guarantee sustainability, in order to develop complementary practices. Involving local populations in governance of ecosystem management plans allows for Blue Carbon to support a steady resource flow into local communities beyond current fragmented financing plans.

In open-ocean ecosystems, management of carbon stocks is also challenged by the movement of carbon across the water column and national and jurisdictional borders (Luisetti et al., 2020). Though occurring naturally, these movements can also be triggered by anthropogenic activities indiscriminately impacting sediment delivery in the water (Crooks et al., 2018). Little is known about valuation of carbon as a transboundary resource and the uncertainty regarding the origin of the carbon makes its valuation challenging. Carbon frameworks in international waters (covering about $60 \%$ of the oceans) are just beginning to take form, mostly relying on voluntary commitments for management. The United Nations Convention on the Law of the Sea (UNCLOS) of 10th December 1982 mentions that "No State may validly purport to subject any part of the high seas to its sovereignty" (article ${ }^{\circ} 89$ ). Defined by the parts of the ocean not included in EEZ, territorial, internal or archipelagic water, this legal criterion of high seas represents about $64 \%$ of the surface of the ocean. This is also the case for seabed ("area") and its resources, which are considered as "common heritage of mankind" (article 136) [United Nations Convention on the Law of the Sea (UNCLOS), 1982]. Activities in such areas are under the control of the International Seabed Authority and shall take into account the principle of protection and conservation of natural resources. This question calls for international innovative coordination and joint strategies, in order to avoid habitat degradation that releases carbon and ensure the integrity of carbon cycling and sequestration. The potential international support granted to Blue Carbon rich countries is one of many incentives arising with cross-sectorial carbon management (Chan, 2021). Other initiatives include the UNEP Regional Seas Program which proposes a shared areas approach based on tackling "ocean grabbing," an issue of powerful stakeholders attempting to secure other resources from the ocean along with carbon rights (Barbesgaard, 2018). Climate change considerations and carbon conservation could be addressed by elements of the ongoing Marine Biodiversity of Areas Beyond National Jurisdiction (BBNJ) treaty negotiations such as area-based management tools (including MPAs), and environmental impact assessment, but climate issues have not risen to a high priority in this historic negotiation (Tessnow-von Wysocki and Vadrot, 2020).

The modernization of joint coordination strategies among different states, and for international waters, among different UN agencies, is necessary in order to define achievable, realistic, and progressive protocols agreements. These would not be sectoral but comprehensive, with an integrated management perspective (involving coastal ecosystems, open water and deep-sea ecosystems with environmental, social and economic questions). Even the UN Conference of Parties (COP) has been shown to benefit from restructuring approaches in order to adapt to the evolving climate crisis and the stakeholders impacted by and involved with its outcomes (Ferrer et al., 2021). Coherency is mandatory to achieve long-term results across domains of fishery management, biodiversity conservation, transport and tourism policing. It is indispensable to foster real management plans from a local level (including methods of ecosystem engineering, the ecological enhancement of marine Blue infrastructure) to an international level (development of MPAs, marine spatial planning (MSP), transnational protected areas and creation of cross-border online platforms for carbon and biodiversity offsets). Platform such as the Ocean and Climate Change dialogue support discussions which can strengthen a common understanding of the gravity of the situation across stakeholders and scale of impact (UNFCCC, 2021). Sustainable management of transboundary marine resources through integrated approaches presents a unique opportunity to avoid conflicts and develop cooperation for shared benefits. Transboundary water pollution and climate change are key areas for improvement (Giupponi and Gain, 2017). Marine ecosystems have no borders and acknowledging connectivity between ecosystems is essential to sustainably manage and develop marine resources to their maximum potential. Thus, marine management can be an opportunity to develop cooperation. Potential approaches include leaders' training programs with the goal to increase awareness with clear and precise communication about the value of Blue Natural Capital, along with clear transboundary management strategies for marine resources with a transboundary diagnostic analysis, and pertinent and achievable strategic action programs (Cziesielski et al., 2021).

Environmental measures should tackle, both, terrestrial and marine ecosystems, with one as a continuum of the other. Coral reef restoration can increase coastal resilience to sea level rise and flooding and provide valuable environmental services for local populations (Hamerkop, 2021). From the opposite direction, water pollution in rivers contributes to ocean ecosystem degradation, via eutrophication and the formation of 
dead zones. River basin management planning (and associated financial mechanisms) must integrate the relationship between freshwater resources and marine ecosystems.

Holistic and integrative concepts are key to account for differences in representation. Implementing natural based solutions (NbS), for which Blue Carbon is one type, could support the integration of this continuum between mitigation/adaptation and terrestrial/marine solutions. NbS can make impactful changes if built for the long-term and continuously measured with the right metrics to support a range of ecosystems and their local communities' rights and needs (Girardin et al., 2021). The success of NbS implementation will depend on close collaboration between a wide range of stakeholders and polycentric governance structure as well as on the clarification of values and interests they have in common (Martin et al., 2021). Outlining specific policy targets for NbS throughout the project duration can strengthen the effectiveness of these strategies (OECD, 2021). This collaborative approach would include citizens, partnerships with environmental organizations and universities, private and public sector and community action and engagement (Cohen-Shacham et al., 2016).

\section{Local Populations}

As mentioned above, local actors are key to the long-term success and development of Blue Carbon ecosystem management schemes, particularly as 120 million people worldwide now live near mangroves (UNEP, 2014). According to the International Federation of the Red Cross and Red Crescent the replanting of mangroves in Vietnam between 1998 and 2002 has reduced the cost of dyke maintenance by $\$ 7.3$ million a year for an investment of $\$ 1.1$ million (International Federation of Red Cross Red Crescent Societies, 2002). Moreover, the Markets and Mangrove project directly links income for the community and mangrove ES, as shrimp farmers now have financial incentives to protect mangroves, with the assurance of higher revenues from their newly obtained organic certification (McEwin and McNally, 2014; Wylie et al., 2016). Similarly, the mangrove restoration program Mikoko Pamoja ${ }^{9}$ in Kenya uses sales from carbon credits to support schooling and the provision of piped water in the community (Wylie et al., 2016). In Indonesia, 13 million metric tons of Blue Carbon have been stopped from release into the atmosphere between 2000 and 2010 due to protected coastal areas, amounting to $\$ 540$ million in social welfare benefits (as calculated by Pendleton et al., 2012; Miteva et al., 2015).

Socio Manglar (Ecuador), a program in which communities receive cash directly for their sustainable management of mangrove forests (Herr et al., 2017) demonstrates that mitigation plans ought to aim for local involvement and governance as an ultimate objective. As previously stated, ES, including carbon sequestration, have a number of costs and benefits which are likely better defined by local populations (Bennett,

\footnotetext{
${ }^{9}$ program Mikoko Pamoja See https://www.mangrovealliance.org/mikokopamoja/
}

2014). However, they have been vastly excluded from decisionmaking processes so far (Hejnowicz et al., 2015). Ownership and accountability are often an obstacle to community-led governance but can be mitigated by introducing external parties such as research institutes to oversee operations (Vanderklift et al., 2019). Wider scale policies, however, risk the exclusion of local communities from decision-making and governance, a better understanding of the social impact of Blue Carbon has proven widely successful in specific localizations so far.

Time presents a challenge for these integrative processes: ecosystem service assessments must be adapted to the timeline of policy decision-making (Ruckelshaus et al., 2015). Overall, successful mitigation plans rely on science to tackle knowledge gaps with branching approaches such as the Integrated Ocean Carbon research (IOC-R, 2021), funding from investors whose interests are well-understood (Vanderklift et al., 2019), financial processes that support local communities, transparency in decision-making, cross-sectorial support and their incorporation in national efforts for climate change mitigation. The "Livelihoods Carbon Fund" in Senegal presents a strong example of such a cyclic plan: using funding from private companies to offset their carbon impact, this initiative started in 2009 supported the planting of 80 million mangroves, which are impacting not only the carbon sequestration potential of the area but also biodiversity (fish, shrimp and oysters mainly) and farming activities, by counteracting salinization of rice fields ${ }^{10}$. These sustainable long-term impacts support poverty alleviation while protecting key ecosystems and mitigating climate change. Thus, sustainable biodiversity and ecosystem management can provide a foundation upon which to build strategies for poverty alleviation and sustainable community maintenance and growth (Bawa et al., 2020).

In order to meet the Paris Agreement and Sustainable Development Goals 14 (conserve and sustainably use the oceans, seas and marine resources) and 13 (take urgent measures to combat climate change and its impacts), Marine Spatial planning (MSP) not only focuses on reducing carbon emissions but must also contribute to net zero commitments of a country. MSP also generates collateral benefits such as the promotion of gender equality, solid and more sustainable rural livelihoods and production of new jobs (among others). These systemic co-benefits promote public participation, information sharing and dissemination in order to raise awareness of climate justice. Furthermore, MSP is a platform upon which local populations can develop a direct line of contact with government institutions, local authorities and the private sector with the aim to preserve marine ecosystems and reap economic benefits. This opportunity empowers communities, which can build their capacity to shift natural sourcing practices toward more sustainable paradigms that could be achieved due to increased awareness and education programs (Cantral et al., 2012; Suzanne et al., 2019).

\footnotetext{
${ }^{10}$ The "Livelihoods Carbon Fund" in Senegal See https://ivelihoods.eu/portfolio/ oceanium-senegal/
} 


\section{Marine Protected Areas}

The implementation of Marine Protected Areas (MPAs) has risen over the last decades as a promising option to mitigate climate change impacts on carbon removal processes, as long as regulation strategies guaranty the integrity of natural carbon stores (Jones et al., 2018; Bindoff et al., 2019). MPAs have emerged as important governance responses to coordinate ecosystem management, resource utilization and biodiversity conservation, and they currently represent $5.3 \%$ of the global ocean and $1.2 \%$ of high seas ${ }^{11}$. MPAs offer more financial stability than carbon markets by securing resource supply and stable regulations (Thomas et al., 2010). These are achieved through cross-sectorial efforts and agreements on jurisdiction and accountability (Howard et al., 2017a). This reliability makes MPAs sustainably beneficial to a country's overall GHG emissions accounting, providing further incentives for their conservation. Protection of the carbon services provided by the coastal ecosystems remains challenged by governance boundaries (such as the UNFCCC) and competing societal needs. MPA design rarely incorporates carbon services, and marine MPAs currently cover and fully protect $<3 \%$ of the oceans ${ }^{12}$. However, 50 World Heritage Sites currently cover $21 \%$ of the global area of documented Blue Carbon ecosystems (29\% of seagrass, $7.2 \%$ of tidal marsh and $8-9 \%$ of mangrove forest) (UNESCO, 2020). In addition, some ecosystem services provided by open-ocean ecosystems are not yet replaceable by human industries, highlighting the importance of protection. Policymaking has focused on coastal ecosystems such as mangrove forests, salt marshes and seagrass meadows, disregarding the potential of open-ocean and deepsea ecosystems to provide support to mitigation efforts. Scotland has begun to view the potential of Blue Carbon as an incentive in its own right for the implementation of MPAs so it can be directly considered by marine management, both on regional and national scales (Laffoley, 2020).

Incentives for the protection of key areas include other ecosystem services provided as well as social benefits derived from ocean protection inclusion in national policies. MPAs continue to present potential for wider protection of key areas, facilitating governance issues and financing opportunities; but there is a need for international frameworks to step in in order to account for the movement of carbon through national borders and to facilitate cost-effectiveness and economic accountability of ocean-based measures. "Other effective area-based conservation measures" (OECMs) can also serve conservation purposes if properly managed while their main aim focuses on sustainable land management (Kalinina et al., 2021). In both cases, Blue Carbon needs to be an incentive for ecosystem protection in its own right, both recognized and sustainably considered by marine management regulations.

Deep-sea ecosystems offer potential for long-term carbon storage in stable conditions, offering yet another path toward climate change mitigation in open waters, along with an array of other ecosystem services. However, the complexity of deep-sea carbon storage presents two main challenges: (1)

\footnotetext{
${ }^{11}$ See http://www.mpatlas.org.

${ }^{12} \mathrm{https} / / / \mathrm{mpatlas} . \mathrm{org}$
}

data regarding the level of risk which can be sustained by these ecosystems and the practical economic valuation of their carbon services as opposed to emission risks is lacking and (2) these ecosystems are currently vulnerable to anthropogenic disturbance but MPAs can alleviate this risk and contribute to sustainable management practices. There is in any case a need for innovative legal and governance frameworks in order to respond to the challenges of Blue Carbon in deep-sea ecosystems, according to the legal statute of "high sea" and "area" (seabed), beyond national jurisdictions.

\section{CONCLUSION}

The Paris Agreement requires serious commitment at a country and industry level to achieve carbon neutrality by 2050 if the world is to avoid breaching the 1.5-2.0 degree ceiling. This looming deadline places demands onto all stakeholders to neutralize and offset carbon emissions. Among potential answers are nature-based solutions, which play a key role in maintaining active carbon sequestration processes and preventing human assisted-nature-based emissions (e.g., from habitat loss and degradation). Because they are both accessible and co-beneficial for local communities, blue nature-based solutions should be paired with dramatically increased efforts to reduce GHG emissions. Similar to terrestrial carbon in forests, the ocean captures carbon in a range of ecosystems (coastal, deep sea and open ocean) which often offer other services with shared benefits across the society.

This paper suggests how these various ocean ecosystems could support mitigation strategies and carbon stock conservation when sustainably managed across sectors. Financing from stakeholders, who would benefit from ecosystem services as well as from carbon credits, requires a transparent and credible system for managing such a market. Although "climate bandwagoning" (Chan, 2021) commonly justifies political and economic action under a cover of climate mitigation, it now needs to translate into applicable and fast-paced governance practices and policies, starting with partnerships with the private sector as well as the expansion of the tax base. These conservation efforts can only succeed if local communities are part of the decision-making process, where they stand to directly benefit from the meaningful employment and steady income that would help ensure ownership of these efforts.

The COVID-19 crisis has clearly demonstrated the consequences of poor management of the natural world. Many believe that COP26 in November 2021 is the best last chance to get the climate change risk under control. We argue that ocean solutions are a key part of the mix and hope that the protection and restoration of marine carbon stocks and sequestration processes will be part of the COP26 discussions since this will also help address the marine biodiversity crisis and reduce risks of impacts to critical ocean system functions. The post-pandemic period presents an opportunity to reboot our paths to economic development by taking into account the potential and the value of ocean system services, starting with 
integrated policies tied to economic, social and environmental recovery strategies. Global partnerships leading to immediate actions are needed to pair social protection with climate action and economic recovery, in order to rebuild and transform economies from an ecological standpoint.

\section{AUTHOR CONTRIBUTIONS}

$\mathrm{NH}$ and LL led the work. LL, MS, and JH-S contributed mainly in the ecological sections. NH, RC, LL, and MB contributed to the economic and policy sections. All the authors contributed to the manuscript and revised the final manuscript.

\section{REFERENCES}

Amador-Castro, F., García-Cayuela, T., Alper, H. S., Rodriguez-Martinez, V., and Carrillo-Nieves, D. (2021). Valorization of pelagic sargassum biomass into sustainable applications: current trends and challenges. J. Environ. Manage. 283:112013. doi: $10.1016 /$ j.jenvman.2021.112013

Atwood, T. B., Witt, A., Mayorga, J., Hammill, E., and Sala, E. (2020). Global patterns in marine sediment carbon stocks. Front. Mar. Sci. 7:165. doi: $10.3389 /$ fmars.2020.00165

Bach, L. T., Stange, P., Taucher, J., Achterberg, E. P., Algueró-Muñiz, M., Horn, H., et al. (2019). The influence of plankton community structure on sinking velocity and remineralization rate of marine aggregates. Global Biogeochem. Cycles 33, 971-994. doi: 10.1029/2019GB006256

Bach, L. T., Tamsitt, V., Gower, J., Hurd, C. L., Raven, J. A., and Boyd, W. (2021). Testing the climate intervention potential of ocean afforestation using the Great Atlantic Sargassum Belt. Nat. Commun. 12:2556. doi: $10.1038 /$ s41467-021-22837-2

Barange, M., Butenschön, M., Yool, A., Beaumont, N., Fernandes, J. A., Martin, A. P., et al. (2017). The cost of reducing the north atlantic ocean biological carbon pump. Front. Mar. Sci. 3:290. doi: 10.3389/fmars.2016.00290

Barbesgaard, M. (2018). Blue growth: savior or ocean grabbing? J. Peasant Stud. 45, 130-149. doi: 10.1080/03066150.2017.1377186

Barnes, D. K., Sands, C. J., Cook, A., Howard, F., Roman Gonzalez, A., MuñozRamirez, C., et al. (2020). Blue carbon gains from glacial retreat along Antarctic fjords: what should we expect? Glob. Chang. Biol. 26, 2750-2755. doi: $10.1111 /$ gcb. 15055

Barnes, D. K., and Tarling, G. A. (2017). Polar oceans in a changing climate. Curr. Biol. 27, R454-R460. doi: 10.1016/j.cub.2017.01.045

Bawa, K. S., Nawn, N., Chellam, R., Krishnaswamy, J., Mathur, V., Olsson, S. B., et al. (2020). Opinion: envisioning a biodiversity science for sustaining human well-being. PNAS 117, 25951-25955. doi: 10.1073/pnas.2018436117

Bax, N., Sands, C. J., Gogarty, B., Downey, R. V., Moreau, C. V., Moreno, B., et al. (2020). Perspective: increasing blue carbon around Antarctica is an ecosystem service of considerable societal and economic value worth protecting. Glob. Chang. Biol. 27, 5-12. doi: 10.1111/gcb.15392

Bayraktarov, E., Saunders, M. I., Abdullah, S., Mills, M., Beher, J., Possingham, H. P., et al. (2016). The cost and feasibility of marine coastal restoration. Ecol. Appl. 26, 1055-1074. doi: 10.1890/15-1077

Beeston, M., Cuyvers, L., and Vermilye, J. (2020). Blue Carbon: Mind the Gap. Geneva: Gallifrey Foundation.

Bennett, J. (2014). Gifted places: the inalienable nature of belonging in place. Environ. Plan. D 32, 658-671. doi: 10.1068/d4913p

Bernal-Ibáñez, A., Gestoso, I., Wirtz, P., Kaufmann, M., Serrão, E. A., CanningClode, J., et al. (2021). The collapse of marine forests: drastic reduction in populations of the family Sargassaceae in Madeira Island (NE Atlantic). Reg. Environ. Change 21:71. doi: 10.1007/s10113-021-01801-2

Bindoff, N. L., Cheung, W. W. L., Kairo, J. G., Arístegui, J., Guinder, V. A., Hallberg, R., et al. (2019). Changing Ocean, Marine Ecosystems, and Dependent Communities. IPCC Special Report on the Ocean and Cryosphere in a Changing Climate.

\section{FUNDING}

The Scientifique Center of Monaco will pay the fees.

\section{ACKNOWLEDGMENTS}

The authors thank Dr. Lina Maria Rassmusson for her constructive comments on a draft of this paper. Phillip Williamson and Valeria Guinder are thanked for their input during initial formulation and structuring of this manuscript. The authors also thank Rashid Sumaila and Cheri Hebert for allowing the use of certain pictures that are part of Figure $\mathbf{1 .}$

Börner, J., Baylis, K., Corbera, E., Ezzine-de-Blas, D., Honey-Rosés, J., Persson, U. M., et al. (2017). The effectiveness of payments for environmental services. World Dev. 96, 359-374. doi: 10.1016/j.worlddev.2017. 03.020

Boyce, J. K. (2018). Carbon pricing: effectiveness and equity. Ecol. Econ. 150, 52-61. doi: 10.1016/j.ecolecon.2018.03.030

Boyd, P. W., Claustre, H., Levy, M., Siegel, D. A., and Weber, T. (2019). Multifaceted particle pumps drive carbon sequestration in the ocean. Nature 568, 327-335. doi: 10.1038/s41586-019-1098-2

Breitbart, M., C., Bonnain, K., and Malki, Sawaya, N. A. (2018). Phage puppet masters of the marine microbial realm. Nat. Microbiol. 3, 754-766. doi: 10.1038/s41564-018-0166-y

Briggs, N., Dall'Olmo, G., and Claustre, H. (2020). Major role of particle fragmentation in regulating biological sequestration of $\mathrm{CO}_{2}$ by the oceans. Science 367, 791-793. doi: 10.1126/science.aay1790

Brown, K., and Adger, W. N. (1994). Economic and political feasibility of international carbon offsets. For. Ecol. Manag. 68, 217-229. doi: 10.1016/0378-1127(94)90047-7

Buesseler, K. O., Boyd, P. W., Black, E. E., and Siegel, D. A. (2020). Metrics that matter for assessing the ocean biological carbon pump. PNAS 117, 9679-9687. doi: 10.1073/pnas.1918114117

Cantral, L., Young, O. R., Dumas, D., Fujita, R., Crowder, L., Burke, L., et al. (2012). Report: Why Value de Oceans, The Economics of Ecosystems and Biodiversity,1-31. Available online at: https://www.cbd.int/financial/values/gvalueoceans-teeb.pdf (accessed July 15, 2021).

Canu, D. M., Ghermandi, A., Nunes, P. A. L. D., Lazzari, P., Cossarini, G., and Solidoro, C. (2015). Estimating the value of carbon sequestration ecosystem services in the Mediterranean Sea: An ecological economics approach. Glob. Environ. Change 32, 87-95. doi: 10.1016/j.gloenvcha.2015.02.008

Chami, R., Cosimano, T., Fullenkamp, C., and Oztosun, S. (2019). Nature's solution to climate change. Finance and Development Magazine, 34-38.

Chami, R., Fullenkamp, C., Cosimano, T., and Berzaghi, F. (2020a). The Secret Work of Elephants. Finance and Development Magazine, 58-62.

Chami, R., Fullenkamp, C., Cosimano, T., Berzaghi, F., Español-Jiménez, S., Marcondes, M., et al. (2020b). On Valuing Nature-Based Solutions to Climate Change: A Framework with Application to Elephants and Whales. Available online at: https://papers.ssrn.com/sol3/papers.cfm?abstract_id=3686168\#

Chan, N. (2021). Linking ocean and climate change governance. Wiley Interdisc. Rev. Clim. Change 12:e711. doi: 10.1002/wcc.711

Chávez, V., Uribe-Martínez, A., Cuevas, E., Rodríguez-Martínez, R. E., van Tussenbroek, B. I., Francisco, V., et al. (2020). Massive influx of pelagic sargassum spp. on the coasts of the Mexican Caribbean 2014-2020: challenges and opportunities. Water.12:2908. doi: 10.3390/w12102908

Choudhary, P., Khade, M., Savant, S., Musale, A., Chelliah, M. S., and Dasgupta, S. (2021). Empowering blue economy: from underrated ecosystem to sustainable industry. J. Environ. Manage. 291:112697. doi: 10.1016/j.jenvman.2021.112697

Cohen-Shacham, E., Walters, G., Janzen, C., and Maginnis, S. (Eds.). (2016). Nature-Based Solutions to Address Global Societal Challenges. Gland: IUCN.

Conservatoire du Littoral (2020). Report of Activities, 2020 "Protéger et Valoriser", 1-12. 
Costanza, R., De Groot, R., Sutton, P., Van der Ploeg, S., Anderson, S. J., Kubiszewski, I., et al. (2014). Changes in the global value of ecosystem services. Glob. Environ. Change 26, 152-158. doi: 10.1016/j.gloenvcha.2014. 04.002

Crooks, S., Sutton-Grier, A. E., Troxler, T. G., Herold, N., Bernal, B., SchileBeers, L., et al. (2018). Coastal wetland management as a contribution to the US National Greenhouse Gas Inventory. Nat. Clim. Change 8, 1109-1112. doi: 10.1038/s41558-018-0345-0

Cziesielski, M. J., Duarte, C. M., Aalismail, N., Al-Hafedh, Y., Anton, A., Baalkhuyur, F., et al. (2021). Investing in Blue Natural Capital to secure a future for the Red Sea ecosystems. Front. Mar. Sci. 7:1183.

Dasgupta, P. (2021). The Economics of Biodiversity: The Dasgupta Review. London: HM Treasury.

Davison, C., Checkley, D. M., Koslow, J. A. Jr., and Barlow, J. (2013). Carbon export mediated by mesopelagic fishes in the northeast Pacific Ocean. Prog. Oceanogr. 116, 14-30. doi: 10.1016/j.pocean.2013.05.013

Diaz-Torres, N. A., Mahon, B. P., Boone, C. D., Pinard, M. A., Tu, C., Ng, R., et al. (2015). Structuraland biophysical characterization of the $\alpha$-carbonicanhydrase from Thiomicrospira crunogena XCL-2 gammaproteobacterium: insights into engineering thermostable enzymes for $\mathrm{CO} 2$ sequestration. Acta Crystallogr. D Biol.Crystallogr. 71,1745-1756. doi: 10.1107/S1399004715 012183

Duarte, C. M., Agusti, S., Barbier, E., Britten, G. L., Castilla, J. C., Gattuso, J. P., et al. (2020). Rebuilding marine life. Nature 580, 39-51. doi: 10.1038/s41586-020-2146-7

Duarte, C. M., Losada, I. J., Hendriks, I. E., Mazarrasa, I., and Marbà, N. (2013). The role of coastal plant communities for climate change mitigation and adaptation. Nat. Clim. Change 3, 961-968. doi: 10.1038/nclimate1970

Duarte, C. M., Wu, J., Xiao, X., Bruhn, A., and Krause-Jensen, D. (2017). Can seaweed farming play a role in climate change mitigation and adaptation? Front. Mar. Sci. 4:100. doi: 10.3389/fmars.2017.00100

Ewers-Lewis, C. J., Baldock, J. A., Hawke, B., Gadd, S., Zawadzki, A., Heijnis, H., et al. (2019). Impacts of land reclamation on tidal marsh 'blue carbon'stocks. Sci. Tot. Environ. 672, 427-437. doi: 10.1016/j.scitotenv.2019.03.345

Fankhauser, S., and an Jotzo, F. (2018). Economic growth and development with low-carbon energy. Wiley Interdiscip. Rev. Clim. Change 9:e495. doi: $10.1002 /$ wcc. 495

FAO (2019). "Deep-ocean climate change impacts on habitat, fish and fisheries," FAO Fisheries and Aquaculture Technical Paper No. 638, eds L. Levin, M. Baker, A. Thompson (Rome, FAO), 186. Licence: CC BY-NC-SA 3.0 IGO.

Ferrer, E. M., Cavole, L. M., Clausnitzer, S., Dias, D. F., Osborne, T. C., Sugla, R., et al. (2021). Entering negotiations: early-career perspectives on the UN Conference of Parties (COP) and the unfolding climate crisis. Front. Mar. Sci. 8:474. doi: 10.3389/fmars.2021.632874

Fillinger, L., Janussen, D., Lundälv, T., and Richter, C. (2013). Rapid glass sponge expansion after climate-induced Antarctic ice shelf collapse. Curr. Biol. 23, 1330-1334. doi: 10.1016/j.cub.2013.05.051

Fisher, B., Turner, K., Zylstra, M., Brouwer, R., De Groot, R., Farber, S., et al. (2008). Ecosystem services and economic theory: integration for policy-relevant research. Ecol. Appl. 18, 2050-2067. doi: 10.1890/07-1 537.1

Flombaum, P., Wang, W. L., Primeau, F. W., and Martiny, A. C. (2020). Global picophytoplankton niche partitioning predicts overall positive response to ocean warming. Nat. Geosci. 13, 116-120. doi: 10.1038/s41561-019-0524-2

Gallo, N. D., Victor, D. G., and Levin, L. A. (2017). Ocean commitments under the Paris Agreement. Nature 833-838. doi: 10.1038/nclimate3422

Gambhir, A., and Tavoni, M. (2019). Direct air carbon capture and sequestration: how it works and how it could contribute to climate-change mitigation. One Earth 1, 405-409. doi: 10.1016/j.oneear.2019.11006

Garrod, G., and Willis, K. G. (1999). Economic Valuation of the Environment. Newcastle upon Tyne: Edward Elgar Publishing.

Gattuso, J. P., Magnan, A. K., Bopp, L., Cheung, W. W., Duarte, C. M., Hinkel, J., et al. (2018). Ocean solutions to address climate change and its effects on marine ecosystems. Front. Mar. Sci. 5:337. doi: 10.3389/fmars.2018.00337

Gedan, K. B., Kirwan, M. L., Wolanski, E., Barbier, E. B., and Silliman, B. R. (2011). The present and future role of coastal wetland vegetation in protecting shorelines: answering recent challenges to the paradigm. Clim. Change 106, 7-29. doi: 10.1007/s10584-010-0003-7
Gedan, K. B., and Silliman, B. R. (2009). "Patterns of salt marsh loss within coastal regions of North America: Presettlement to present," in Human Impacts on Salt Marshes: A Global Perspective, eds B. R. Silliman, E. D. Grosholz, and M. D. Bertness (Los Angeles, CA: University of California Press), 253-266.

Gedan, K. B., Silliman, B. R., and Bertness, M. D. (2009). Centuries of humandriven change in salt marsh ecosystems. Ann. Rev. Mar. Sci. 1, 117-141. doi: 10.1146/annurev.marine.010908.163930

Gehlen, M., Séférian, R., Jones, D. O. B., Roy, T., Roth, R., Barry, J., et al. (2014). Projected $\mathrm{pH}$ reductions by 2100 might put deep North Atlantic biodiversity at risk. Biogeosciences 11, 6955-6967. doi: 10.5194/bg-11-6955-2014

Girardin, C. A. J., Jenkins, S., Seddon, N., Allen, M., Lewis, S. L., Wheeler, C. E., et al. (2021). Nature-based solutions can help cool the planet - if we act now. Nature 593, 191-194. doi: 10.1038/d41586-021-01241-2 PMID: 33981055.

Giupponi, C., and Gain, A. K. (2017). Integrated water resources management (IWRM) for climate change adaptation. Reg. Environ. Change 17, 1865-1867. doi: 10.1007/s10113-017-1173-x

Gogarty, B., McGee, J., Barnes, D. K., Sands, C. J., Bax, N., Haward, M., et al. (2020). Protecting Antarctic blue carbon: as marine ice retreats can the law fill the gap?. Clim. Policy 20, 149-162. doi: 10.1080/14693062.2019.1694482

Goldberg, L., Lagomasino, D., Thomas, N., and Fatoyinbo, T. (2020). Global declines in human-driven mangrove loss. Glob. Chang. Biol. 26, 5844-5855. doi: $10.1111 /$ gcb.15275

Gouvêa, L. P., Assis, J., Gurgel, C. F., Serrão, E. A., Silveira, T. C., Santos, R., et al. (2020). Golden carbon of Sargassum forests revealed as an opportunity for climate change mitigation. Sci. Tot. Environ. 729:138745. doi: $10.1016 /$ j.scitotenv.2020.138745

Greiner, J. T., McGlathery, K. J., Gunnell, J., and McKee, B. A. (2013). Seagrass restoration enhances "blue carbon" sequestration in coastal waters. PLoS ONE 8:e72469. doi: 10.1371/journal.pone.0072469

Gullström, M., Dahl, M., Lindén, O., Vorhies, F., Forsberg, S., Ismail, R. O., et al. (2021). Coastal Blue Carbon Stocks in Tanzania and Mozambique. IUCN Global Marine and Polar Programme.

Hale, R., Godbold, J. A., Sciberras, M., Dwight, J., Wood, C., Hiddink, J. G., et al. (2017). Mediation of macronutrients and carbon by postdisturbance shelf sea sediment communities. Biogeochemistry 135, 121-133. doi: 10.1007/s10533-017-0350-9

Hamerkop (2021). Emerging of Natural Climate Solutions: Who and How? Available online at: https://www-hamerkop-co.cdn.ampproject.org/c/s/www. hamerkop.co/blog/emerging-of-natural-climate-solutions-who-and-how? format=amp

Han, T., Shi, R., Qi, Z., Huang, H., Wu, F., and Gong, X. (2020). Biogenic acidification of Portuguese oyster Magallana angulata mariculture can be mediated through introducing brown seaweed Sargassum hemiphyllum. Aquaculture. 520:734972. doi: 10.1016/j.aquaculture.2020.734972

Hansell, D. A., Carlson, C. A., Repeta, D. J., and Schlitzer, R. (2009) Dissolved organic matter in the ocean: a controversy stimulates new insights. Oceanography. 22, 202-211. doi: 10.5670/oceanog.2009.109

Hejnowicz, A. P., Kennedy, H., Rudd, M. A., and Huxham, M. R. (2015). Harnessing the climate mitigation, conservation and poverty alleviation potential of seagrasses: prospects for developing blue carbon initiatives and payment for ecosystem service programmes. Front. Mar. Sci. 2:32. doi: $10.3389 /$ fmars.2015.00032

Herr, D., and Landis, E. (2016). Coastal blue carbon ecosystems. Opportunities for Nationally Determined Contributions. Policy Brief. Gland; Washington, DC: IUCN; TNC.

Herr, D., von Unger, M., Laffoley, D., and McGivern, A (2017). Pathways for implementation of blue carbon initiatives. Aquat. Conserv. 27, 116-129. doi: 10.1002/ aqc. 2793

Hiraishi, T., Krug, T., Tanabe, K., Srivastava, N., Baasansuren, J., Fukuda, M., et al. (2014). 2013 Supplement to the 2006 IPCC Guidelines for National Greenhouse Gas Inventories: Wetlands. IPCC.

Howard, J., McLeod, E., Thomas, S., Eastwood, E., Fox, M., Wenzel, L., et al. (2017a). The potential to integrate blue carbon into MPA design and management. Aquat. Conserv. 27, 100-115. doi: 10.1002/aqc.2809

Howard, J., Sutton-Grier, A., Herr, D., Kleypas, J., Landis, E., Mcleod, E., et al. (2017b). Clarifying the role of coastal and marine systems in climate mitigation. Front. Ecol. Environ. 15, 42-50. doi: 10.1002/fee.1451 
Hu, C., Wang, M., Lapointe, B. E., Brewton, R. A., and Hernandez, F. J. (2021). On the Atlantic pelagic Sargassum's role in carbon fixation and sequestration. Sci. Tot. Environ. 781:146801. doi: 10.1016/j.scitotenv.2021.146801

International Federation of Red Cross Red Crescent Societies, and Centre for Research on the Epidemiology of Disasters (2002). World Disasters Report. International Federation of Red Cross and Red Crescent Societies.

IOC-R (2021). Integrated Ocean Carbon Research: A Summary of Ocean Carbon Research, and Vision of Coordinated Ocean Carbon Research and Observations for the Next Decade. IOC Technical Series. 158, eds R. Wanninghof, C. Sabine and S. Aricò (Paris, UNESCO), 46.

IPCC (2019). IPCC Special Report on the Ocean and Cryosphere in a Changing Climate, eds H.-O. Pörtner, D. C. Roberts, V. Masson-Delmotte, P. Zhai, M. Tignor, E. Poloczanska, et al.

Irving, A. D., Connell, S. D., and Russell, B. D. (2011). Restoring coastal plants to improve global carbon storage: reaping what we sow. PLoS ONE 6:e18311. doi: 10.1371/journal.pone.0018311

Jin, D., Hoagland, P., and Buesseler, K. O. (2020). The value of scientific research on the ocean's biological carbon pump. Sci. Total. Environ. 749:141357. doi: 10.1016/j.scitotenv.2020.141357

Jones, K. R., Klein, C. J., Halpern, B. S., Venter, O., Grantham, H., Kuempel, C. D., et al. (2018). The location and protection status of Earth's diminishing marine wilderness. Curr. Biol. 28, 2506-2512. doi: 10.1016/j.cub.2018.06.010

Kalinina, M., Briggs, J., and O'Connor Villagomez, A. (2021). To Achieve 30\% Ocean Protection Governments Can Look Beyond Conventional Tools. PEW. Available online at: https://www-pewtrusts-org.cdn.ampproject.org/c/s/www. pewtrusts.org/en/research-and-analysis/articles/2021/05/07/to-achieve-30ocean-protection-governments-can-look-beyond-conventional-tools? $\mathrm{amp}=1$

Keith, H., Vardon, M., Obst, C., Young, V., Houghton, R. A., and Mackey, B. (2021). Evaluating nature-based solutions for climate mitigation and conservation requires comprehensive carbon accounting. Sci. Tot. Environ. 769:144341. doi: 10.1016/j.scitotenv.2020.144341

Kiko, R., and Hauss, H. (2019). On the estimation of zooplankton-mediated active fluxed in Oxygen Minimum Zone regions. Front. Mar. Sci. 6:741. doi: $10.3389 /$ fmars.2019.00741

Kirwan, M. L., and Mudd, S. M. (2012). Response of salt-marsh carbon accumulation to climate change. Nature 489, 550-553. doi: 10.1038/nature11440

Klein, J. (2021). Apple, Conservation International Introduce Mangrove Carbon Credit. Green Biz. Available online at: https://www.greenbiz.com/article/appleconservation-international-introduce-mangrove-carbon-credit

Kletou, D., Savva, I., Tsiamis, K., and Hall-Spencer, J. M. (2018). Opportunistic seaweeds replace Cystoseira forests on an industrialised coast in Cyprus. Mediterr. Mar. Sci. 19, 598-610. doi: 10.12681/mms.16891

Konar, M., and Ding, H. (2020). A Sustainable Ocean Economy for (2050). Secretariat of the High Level Panel for a Sustainable Ocean Economy. World Resources Institute. Available online at: https://oceanpanel.org/sites/default/ files/202007/Ocean\%20Panel_Economic\%20Analysis_FINAL.pdf

Kosoy, N., and Corbera, E. (2010). Payments for ecosystem services as commodity fetichism. Ecol. Econ. 69, 1228-1236. doi: 10.1016/j.ecolecon.2009.11.002

Krause-Jensen, D., and Duarte, C. M. (2016). Substantial role of macroalgae in marine carbon sequestration. Nat. Geosci. 9, 737-742. doi: 10.1038/NGEO2790

Kroeger, K. D., Crooks, S., Moseman-Valtierra, S., and Tang, J. (2017). Restoring tides to reduce methane emissions in impounded wetlands: a new and potent Blue Carbon climate change intervention. Sci. Rep. 7, 1-12. doi: 10.1038/s41598-017-12138-4

Laffoley, D. (2020). Protecting and Effectively Managing Blue Carbon Ecosystems to Realise the Full Value to Society - A Sea of Opportunities. Opinion piece for WWF-UK. Woking, Surrey.

Laffoley, D., Baxter, J. M., Amon, D. J., Currie, D. E., Downs, C. A., Hall-Spencer, J. M., et al. (2020). Eight urgent, fundamental and simultaneous steps needed to restore ocean health, and the consequences for humanity and the planet of inaction or delay. Aquat. Conserv. Mar. Freshw. Ecosyst. 30, 194-208.

Laffoley, D., and Grimsditch, G. D. (Eds.). (2009). The Management of Natural Coastal Carbon Sinks. IUCN.

Landrigan, J., Stegeman, J. J., Fleming, L. E., Allemand, D., Anderson, D. M., Backer, L. C., et al. (2020). Human health and ocean pollution. Ann. Global Health 86, 1-64. doi: 10.5334/aogh.2831
Laurans, Y., Ruat, R., and Barthélémy, P. (2016). Counting on nature: how governments plan to rely on ecosystems for their climate strategies: an analysis based on Intended Nationally Determined Contributions and the Paris Agreement. IDDRI Issues Brief No5 Biodiversity. Institute du developpement durable et des relations internationales, Paris, France.

Legendre, L., Rivkin, R. B., Weinbauer, M. G., Guidi, L., and Uitz, J. (2015). The microbial carbon pump concept: potential biogeochemical significance in the globally changing ocean. Progr. Oceanogr.134, 432-450. doi: $10.1016 /$ j.pocean.2015.01.008

Levallois, O. (2020). The Essential of Climate Finance - A Beginner Guide, HAMERKOP Climate Impacts. Available online at: https://www.hamerkop.co/ blog/the-essential-of-climate-finance-a-beginner-guide

Levin, L. A., and Le Bris, N. (2015). Deep oceans under climate change. Science 350, 766-768. doi: 10.1126/science.aad0126

Levin, L. A., Wei, C. L., Dunn, D. C., Diva, J. A., Ashford, O. S., Cheung, W. W., et al. (2020). Climate change considerations are fundamental to management of deep-sea resource extraction. Glob. Chang. Biol. 26:4664-78. doi: $10.1111 / \mathrm{gcb} .15223$

Luisetti, T., Ferrini, S., Grilli, G., Jickells, T. D., Kennedy, H., Kröger, S., et al. (2020). Climate action requires new accounting guidance and governance frameworks to manage carbon in shelf seas. Nat. Commun. 11, 1-10. doi: 10.1038/s41467-020-18242-w

Macreadie, I., Nielsen, D. A., Kelleway, J. J., Atwood, T. B., Seymour, J. R., Petrou, K., et al. (2017). Can we manage coastal ecosystems to sequester more blue carbon? Front. Ecol. Environ. 15, 206-213. doi: 10.1002/fee.1484

Mahon, B. P., Bhatt, A., Vulla, D., Supuran, C. T., and McKenna, R. (2015). Exploration of anionic inhibition of the $\alpha$-carbonic anhydrase from Thiomicrospira crunogena XCL- 2 gammaproteobacterium: a potential biocatalytic agent for industrial CO2 removal. Chem. Eng. Sci. 138, 575-580. doi: 10.1016/j.ces.2015.07.030

Mansouri, N. R., Chami, R., Duarte, C. M., Lele, Y., Mathur, M., and Osman, A. (2020). Policy Brief: nature-based solutions to climate change: towards a blue carbon economy future. G20 Insights. 1, 1-23. Available online at: https:// www.g20-insights.org/wp-content/uploads/2020/11/nature-based-solutionsto-climate-change-towards-a-blue-carbon-economy-future-1606067129.pdf

Mariani, G., Cheung, W. W., Lyet, A., Sala, E., Mayorga, J., Velez., et al. (2020). Let more big fish sink: fisheries prevent blue carbon sequestration - half in unprofitable areas. Sci. Adv. 6:abb4848. doi: 10.1126/sciadv.abb4848

Martin, J. G., Scolobig, A., Linnerooth-Bayer, J., Liu, W., and Balsiger, J. (2021). Catalyzing innovation: governance enablers of nature-based solutions. Sustainability 13:1971. doi: 10.3390/su13041971

Martin, S. L., Balance, L. T., and Groves, T. (2016). An ecosystem services perspective for the oceanic eastern tropical pacific: commercial fisheries, carbon storage, recreational fishing, and biodiversity. Front. Mar. Sci. 3:50. doi: 10.3389 /fmars.2016.00050

Martinetto, P., Alemany, D., Botto, F., Mastrángelo, M., Falabella, V., Acha, E. M., et al. (2020). Linking the scientific knowledge on marine frontal systems with ecosystem services. Ambio 49, 541-556. doi: 10.1007/s13280-019-01222-w

McEwin, A., and McNally, R. (2014). Organic Shrimp Certification and Carbon Financing: An Assessment for the Mangroves and Markets Project in Ca Mau Province, Vietnam, ed Ca Mau, REAP Project SNV, 81.

Merzouk, A., and Johnson, L. E. (2011). Kelp distribution in the northwest Atlantic Ocean under a changing climate. J. Exp. Mar. Biol. Ecol. 400, 90-98. doi: 10.1016/j.jembe.2011.02.020

Metcalf, G. E., and Stock, J. H. (2017). Integarted assessment models and the social cost of carbon: a review and assessment of US experience. Rev. Environ. Econ. Policy 11, 80-99. doi: 10.1093/reep/rew014

Millero, F. J. (2007). The marine inorganic carbon cycle. Chem. Rev. (2007) 107, 308-341. doi: 10.1021/cr0503557

Miteva, D. A., Murray, B. C., and Pattanayak, S. K. (2015). Do protected areas reduce blue carbon emissions? A quasi-experimental evaluation of mangroves in Indonesia. Ecol. Econ. 119, 127-135. doi: 10.1016/j.ecolecon.2015.08.005

Mora, C., Wei, C. L., Rollo, A., Amaro, T., Baco, A. R., Billett, D., et al. (2013). Biotic and human vulnerability to projected changes in ocean biogeochemistry over the $21^{\text {st }}$ century. PLoS Biol. 11:e1001682. doi: 10.1371/journal.pbio.1001682

Morato, T., González-Irusta, J. M., Dominguez-Carrió, C., Wei, C. L., Davies, A., Sweetman, A. K., et al. (2020). Climate-induced changes in the suitable habitat 
of cold-water corals and commercially important deep-sea fishes in the North Atlantic. Glob. Chang. Biol. 26, 2181-2202. doi: 10.1111/gcb.14996

Narita, D., Poertner, H.-O., and Rehdanz, K. (2020). Accounting for risk transitions of ocean ecosystems under climate change: an economic justification for more ambitious policy responses. Clim. Change 162, 1-11. doi: $10.1007 / \mathrm{s} 10584-020-02763-\mathrm{w}$

OECD (2016). The Ocean Economy in 2030 Report, OECD publishing, Paris.

OECD (2021). Scaling Up Nature-Based Solutions to Tackle Water-Related Climate Risks: Insights From Mexico and the United Kingdom, OECD Publishing, Paris.

Pendleton, L., Donato, D. C., Murray, B. C., Crooks, S., Jenkins, W. A., Sifleet, S., et al. (2012). Estimating global "blue carbon" emissions from conversions and degradation of vegetated coastal ecosystems. PLoS ONE 7:e43542. doi: 10.1371/journal.pone.0043542

Pessarrodona, A., Moore, P. J., Sayer, M. D., J., and Smale, D, A. (2018). Carbon assimilation and transfer through kelp forests in the NE Atlantic is diminished under a warmer ocean climate. Glob. Change Biol. 24, 4386-4398. doi: $10.1111 /$ gcb. 14303

Pusceddu, A., Bianchelli, S., Martín, J., Puig, P., Palanques, A., Masqué, P., et al. (2014). Chronic and intensive bottom trawling impairs deepsea biodiversity and ecosystem functioning. PNAS 111, 8861-8866. doi: $10.1073 /$ pnas. 1405454111

Queirós, A. M., Stephens, N., Widdicombe, S., Tait, K., McCoy, S. J., Ingels, J., et al. (2019). Connected macroalgal-sediment systems: blue carbon and food webs in the deep coastal ocean. Ecol. Monogr. 89:e01366. doi: 10.1002/ecm.1366

Quevedo, J. M. D., Uchiyama, Y., Muhmad Lukman, K., and Kohsaka, R. (2021). how blue carbon ecosystems are perceived by local communities in the coral triangle: comparative and empirical examinations in the Philippines and Indonesia. Sustainability 13:127. doi: 10.3390/su13010127

Raghav, S., Siman, K., Gross, A., Wu, A., Zeng, Y., Comstock, M., et al. (2020). Report: The Business Case for Natural Climate Solutions: Insights and Opportunities for Southeast Asia (TemasekConservation International | National University of Singapore), Singapore, 1-109.

Resiere, D., Valentino, R., Nevière, R., Banydeen, R., Gueye, P., Florentin, J., et al. (2018). Sargassum seaweed on Caribbean islands: an international public health concern. Lancet 392:2691. doi: 10.1016/S0140-6736(18)32777-6

Richardson, T. L. (2019). Mechanisms and pathways of small-phytoplankton export from the surface ocean. Ann. Rev. Mar. Sci. 11, 57-74. doi: 10.1146/annurev-marine-121916-063627

Riosmena-Rodriguez, R., Nelson, W., and Aguirre, J. (2017). Rhodolith/Maerl Beds: A Global Perspective. Boca Raton, FL: Springer. doi: 10.1007/978-3-319-29315-8

Rose, K. A., Gutiérrez, D., Breitburg, D., Conley, D., Craig, J. K., Froehlich, H. E., et al. (2019). "Impacts of ocean deoxygenation on fisheries," in Ocean Deoxygenation: Everyone's Problem - Causes, Impacts, Consequences and Solutions, eds D. Laffoley and J. M. Baxter (Gland), 519-544.

Rosentreter, J. A., Al-Haj, A. N., Fulweiler, R. W., and Williamson, P. (2021). Methane and nitrous oxide emissions complicate coastal blue carbon assessments. Glob. Biogeochem. Cycles 35:e2020GB006858. doi: 10.1029/2020GB006858

Rosentreter, J. A., and Williamson, P. (2020). Concerns and uncertainties relating to methane emissions synthesis for vegetated coastal ecosystems. Glob. Chang. Biol. 16, 71-73. doi: 10.1111/gcb.15201

Ruckelshaus, M., McKenzie, E., Tallis, H., Guerry, A., Daily, G., Kareiva, P., et al. (2015). Notes from the field: lessons learned from using ecosystem service approaches to inform real-world decisions. Ecol. Econ. 115, 11-21. doi: 10.1016/j.ecolecon.2013.07.009

Ruppel, C. D., and Kessler, J. D. (2017). The interaction of climate change and methane hydrates. Rev. Geophys. 55, 126-168, doi: 10.1002/2016RG000534

Saderne, V., Fusi, M., Thomson, T., Dunne, A., Mahmud, F., Roth, F., et al. (2020). Total alkalinity production in a mangrove ecosystem reveals and overlooked Blue Carbon component. LandO Lett. 6, 61-67. doi: 10.1002/lol2.10170

Sala, E., Mayorga, J., Bradley, D., et al. (2021). Protecting the global ocean for biodiversity, food and climate. Nature 592, 397-402. doi: 10.1038/s41586-021-03371-z

Santos, I. R., Burdige, D. J., Jennerjahn, T. C., Bouillon, S., Cabral, A., Serrano, O., et al. (2021). The renaissance of Odum's out welling hypothesis in 'Blue Carbon' science. Estuar. Coastal Shelf Sci. 255, 1-9. doi: 10.1016/j.ecss.2021.107361

Sciberras, M., Parker, R., Powell, C., Robertson, C., Kröger, S., Bolam, S., et al. (2016). Impacts of bottom fishing on the sediment infaunal community and biogeochemistry of cohesive and non-cohesive sediments. Limnol. Oceanogr. 61, 2076-2089. doi: 10.1002/lno.10354

Siegel, P. B., and Jorgensen, S. (2011). No-Regrets Approach to Increased Resilience and Climate Change Justice: Toward a Risk Adjusted Social Protection Floor. World Bank, 1-71. Available online at: https://www.ids.ac.uk/download.php?file=files/dmfile/ SiegelJorgensen2011RiskAdjustedSocialProtectionFloor02CSPconferencedraft. pdf

Smale, D. A., Moore, J., Queirós, A. M., Higgs, S., and Burrows, M. T. (2018). Appreciating interconnectivity between habitats is key to blue carbon management. Front. Ecol. Environ. 16, 71-73. doi: 10.1002/fee.1765

Sondak, C. F., and Chung, I. K. (2015). Potential blue carbon from coastal ecosystems in the Republic of Korea. Ocean Sci. J. 50, 1-8. doi: 10.1007/s12601-015-0001

Steinberg, D. K., and Landry, M. R. (2017). Zooplankton and the ocean carbon cycle. Annu. Rev. Mar. Sci. 9, 413-444. doi: 10.1146/annurev-marine-010814-015924

Strydom, S., Murray, K., Wilson, S., Huntley, B., Rule, M., Heithaus, M., et al. (2020). Too hot to handle: unprecedented seagrass death driven by marine heatwave in a World Heritage Area. Glob. Chang. Biol. 26, 3525-3538. doi: $10.1111 /$ gcb. 15065

Su, J., Cai, W. J., Brodeur, J., Chen, B., Hussain, N., Yao, Y., et al. (2020). Chesapeake Bay acidification buffered by spatially decoupled carbonate mineral cycling. Nat. Geosci. 13, 441-447. doi: 10.1038/s41561-0200584-3

Sulpis, O., Boudreau, B. P., Mucci, A., Jenkins, C., Trossman, D. S., Arbic, B. K., et al. (2018). Current $\mathrm{CaCO}_{3}$ dissolution at the seafloor caused by anthropogenic $\mathrm{CO}_{2}$. PNAS 115, 11700-11705. doi: 10.1073/pnas. 1804250115

Sun, F., and Carson, R. T. (2020). Coastal wetlands reduce property damage during tropical cyclones. PNAS 117, 5719-5725. doi: 10.1073/pnas.1915169117

Suzanne, O., Gretchen, E., and Brenden, J. (2019). Nature-Based Solutions for Disaster Risk Management: Booklet (English). Washington, DC: World Bank Group. Available online at: http://documents.worldbank.org/curated/en/ 253401551126252092/Booklet

Sweetman, A. K., Thurber, A. R., Smith, C. R., Levin, L. A., Mora, C., Wei, C. L., et al. (2017). Major impacts of climate change on deep-sea benthic ecosystems. Elem. Sci. Anth. 5:4. doi: 10.1525/elementa.203

Tang, J., Ye, S., Chen, X., Yang, H., Sun, X., Wang, F., et al. (2018). Coastal blue carbon: concept, study method, and the application to ecological restoration. Sci. China Earth Sci. 61, 637-646. doi: 10.1007/s11430-017-9181-x

Tessnow-von Wysocki, I., and Vadrot, A. B. (2020). The voice of science on marine biodiversity negotiations: a systematic literature review. Front. Mar. Sci. 7:614282. doi: 10.3389/fmars.2020.614282

Thamo, T., and Pannell, D. J. (2016). Challenges in developing effective policy for soil carbon sequestration: perspectives on additionality, leakage, and permanence. Climate Policy 16, 973-992. doi: 10.1080/14693062.2015.1075372

The World Bank (2019). Healthy Oceans, Healthy Economies, Healthy Communities.

Thiébault, S., and Moatti, J.-P. (2016). The mediterranean region under climate change a scientific update. French Natl. Alliance Environ. Res. 1, 1-133. doi: 10.4000/books.irdeditions.24549

Thomas, S., Dargusch, P., Harrison, S., and Herbohn, J. (2010). Why are there so few afforestation and reforestation Clean Development Mechanism projects? Land Use Policy 27, 880-887. doi: 10.1016/j.landusepol.2009.12.002

Thompson, T. M., Young, B. R., and Baroutian, S. (2020). Pelagic Sargassum for energy and fertiliser production in the Caribbean: a case study on Barbados. Renew. Sustain. Energy Rev. 118:109564. doi: 10.1016/j.rser.2019.109564

Thurber, A. R., Sweetman, A. K., Narayanaswamy, B. E., Jones, D. O., Ingels, J., and Hansman, R. L. (2014). Ecosystem function and services provided by the deep sea. Biogeosciences 11, 3941-3963. doi: 10.5194/bg-11-3941-2014

Trueman, C. N., Johnston, G., O'Hea, B., and MacKenzie, K. M. (2014). Trophic interactions of fish communities at midwater depths enhance long term carbon storage and benthic production on continental slopes. Proc. R. Soc. B 281:20140669. doi: 10.1098/rspb.2014.0669

Ullman, R., Bilbao-Bastida, V., and Grimsditch, G. (2013). Including blue carbon in climate market mechanisms. Ocean Coastal Manage. 83, 15-18. doi: 10.1016/j.ocecoaman.2012.02.009

UNEP (2014). Annual Report. ISBN: 978-92-807-3442-3 
UNESCO (2020). UNESCO Marine World Heritage: Custodians of the Globe's Blue Carbon Assets. Paris.

UNFCCC (2021). Ocean and Climate Change Dialogue to Consider How to Strengthen Adaptation and Mitigation Action.

United Nations Convention on the Law of the Sea (UNCLOS) (1982). 10th December, 1982. art. $n^{\circ} 89$. Available online at: https://www.un.org/depts/los/ convention_agreements/texts/unclos/unclos_e.pdf

Van Tussenbroek, B. I., Arana, H. A. H., Rodríguez-Martínez, R. E., EspinozaAvalos, J., Canizales-Flores, H. M., González-Godoy, C. E., et al. (2017). Severe impacts of brown tides caused by Sargassum spp. on nearshore Caribbean seagrass communities. Mar. Pollut. Bull. 122, 272-281. doi: 10.1016/j.marpolbul.2017.06.057

Vanderklift, M. A., Marcos-Martinez, R., Butle, J. R. A., Coleman, M., Lawrence, P., Anissa, H., et al. (2019). Constraints and opportunities for market-based finance for the restoration and protection of blue carbon ecosystems. Mar. Policy 107:103429. doi: 10.1016/j.marpol.2019.02.0010

Wada, S., Agostini, S., Harvey, B. P., Omori, Y., and Hall-Spencer, J. M. (2021). Ocean acidification increases phytobenthic carbon fixation and export in a warm-temperate system. Estuar. Coast. Shelf Sci. 250:107113. doi: $10.1016 /$ j.ecss.2020.107113

Waycott, M., Duarte, C. M., Carruthers, T. J. B., Orth, R. J., Dennison, W. C. P., Olyarnik, S., et al. (2009). Accelerating loss of seagrasses across the globe threatens coastal ecosystems. Proc. Natl Acad. Sci. 106, 12377-12381. doi: 10.1073/pnas.0905620106

Weyer, N. M., Cifuentes-Jara, M., Frölicher, T., Jackson, M., Kudela, R. M., Masson-Delmotte, V., et al. (2019). “Annex I: glossary," in IPCC Special Report on the Ocean and Cryosphere in a Changing Climate, eds H.-O. Pörtner, D. C. Roberts, V. Masson-Delmotte, P. Zhai, M. Tignor, E. Poloczanska, et al. Intergovernmental Panel on Climate Change.

Williamson, P., Wallace, D. W., Law, C. S., Boyd, W., Collos, Y., Croot, P., et al. (2012). Ocean fertilization for geoengineering: a review of effectiveness, environmental impacts and emerging governance. Proc. Saf. Environ. Protect. 90, 475-488. doi: 10.1016/j.psep.2012. 10.007

Wilson, A. M. W., and Forsyth, C. (2018). Restoring near-shore marine ecosystems to enhance climate security for island ocean states: aligning international processes and local practices. Mar. Policy 93, 284-294. doi: 10.1016/j.marpol.2018.01.018
Windham-Myers, L., Crooks, S., and Troxler, T. G. (eds.). (2018). A Blue Carbon Primer: The State of Coastal Wetland Carbon Science, Practice, and Policy (1st ed.). CRC Press. doi: 10.1201/9780429435362

Worden, A. Z., Follows, M. J., Giovannoni, S. J., Wilken, S., Zimmerman, A. E., and Keeling, P. J. (2015). Rethinking the marine carbon cycle: factoring in the multifarious lifestyles of microbes. Science 347:1257594. doi: $10.1126 /$ science. 1257594

Worm, B. (2017). How to heal an ocean. Nature 543, 630-631. doi: $10.1038 /$ nature21895

Wylie, L., Sutton-Grier, A. E., and Moore, A. (2016). Keys to successful blue carbon projects: lessons learned from global case studies. Mar. Policy 65,76-84. doi: 10.1016/j.marpol.2015.12.020

Yang, P., Yao, Y. F., Mi, Z., Cao, Y. F., Liao, H., Yu, B. Y., et al. (2018). (Social cost of carbon under shared socioeconomic pathways. Glob. Environ. Change 53, 225-232. doi: 10.1016/j.gloenvcha.2018.10.001

Yool, A., Martin, A. P., Anderson, T. R., Bett, B. J., Jones, D. O., and Ruhl, H. A. (2017). Big in the benthos: future change of seafloor community biomass in a global, body size-resolved model. Glob. Change. Biol. 23, 3554-3566. doi: $10.1111 /$ gcb.13680

Conflict of Interest: The authors declare that the research was conducted in the absence of any commercial or financial relationships that could be construed as a potential conflict of interest.

Publisher's Note: All claims expressed in this article are solely those of the authors and do not necessarily represent those of their affiliated organizations, or those of the publisher, the editors and the reviewers. Any product that may be evaluated in this article, or claim that may be made by its manufacturer, is not guaranteed or endorsed by the publisher.

Copyright (c) 2021 Hilmi, Chami, Sutherland, Hall-Spencer, Lebleu, Benitez and Levin. This is an open-access article distributed under the terms of the Creative Commons Attribution License (CC BY). The use, distribution or reproduction in other forums is permitted, provided the original author(s) and the copyright owner(s) are credited and that the original publication in this journal is cited, in accordance with accepted academic practice. No use, distribution or reproduction is permitted which does not comply with these terms. 